\title{
15
}

\section{No fruit on that beautiful shore: What plants were introduced to the subtropical Polynesian islands prior to European contact?}

\author{
Matthew Prebble \\ Department of Archaeology and Natural History, Australian National University, Australia \\ matiu@coombs.anu.edu.au
}

\section{Introduction}

The introduction of plants to Remote Oceania has been a subject alluded to throughout the development of Pacific botany (e.g. Seemann 1865-73; Guppy 1906; Ridley 1930; Brown 1935; Merrill 1946) and is important given the potential overlapping roles of natural dispersal (e.g. Carquist 1996) and human introduction in shaping island floras. In recent ethnobotanical treatments of Remote Oceania (e.g. Kirch and Yen 1982; Whistler 1991) and in a number of floral compendiums of island archipelagos (e.g. Wagner et al. 1990; Florence 1997, 2004), there has been a tendency for the introduced botanical status of plant species to be given on the basis of their human introduction potential. This potential may include, for any plant, its ethnographic, historical or current status of human utility as wild (natural), domesticated or feral. In this paper, I address a number of additional sources of botanical information, including palaeobotanical and archaeobotanical data, as a means of better defining the human introduction potential of a range of plant taxa. This human introduction potential of many species is discussed with particular reference to New Zealand, where relatively few Polynesian plant introductions have been described with any certainty.

Of the 11 subtropical islands, both $>4 \mathrm{~km}^{2}$ in area and situated south of the Tropic of Capricorn ( $\left.23^{\circ} 26^{\prime} 22^{\prime \prime} S\right)$, there is no evidence that Lord Howe, Alejandro Selkirk, Robinson Crusoe and San Ambosio were ever colonised before European arrival (Anderson 2001). Four islands, including Henderson, Pitcairn, Norfolk and Raoul, were colonised and then abandoned before European arrival (Anderson 1980, 1996; Weisler 1995). Three small islands, including Raivavae, Rapa, Rapanui and the largest Polynesian island, New Zealand, were apparently occupied continuously after initial colonisation. Based on recently constructed archaeological 
chronologies, Polynesian colonisation took place between 800 and $700 \mathrm{cal}$. BP (Higham et al. 1999; Hogg et al. 2003; Kennett et al. 2006; Hunt and Lipo 2006). In this study of the introduced floras of the subtropical islands of Remote Oceania, I focus on all the Polynesian islands including Raivavae, Henderson, Pitcairn, Rapanui, Rapa, Norfolk and Raoul (Figure 1, Table 1 and Table 2).

The floras of Raivavae, Henderson and Pitcairn are derived largely from the western Pacific, species having mainly dispersed via island archipelagos stretching from the Indo-Malaysian basin. Rapa has a strong floral affinity with Norfolk and New Zealand, but also retains many Indo-Malaysian elements. Raoul has a predominant New Zealand flora, but shares a number of elements with Norfolk Island, which has a floral affinity with both New Caledonia and New Zealand. By contrast, Rapanui retains a predominantly American flora, with some IndoMalaysian elements.

The defining characteristic of the indigenous subtropical island floras is the attenuated representation of Indo-Malaysian elements. Coastal strand taxa like Scaevola taccada (Goodeniaceae) and Calophyllum inophyllum (Clusiaceae) common to most tropical Pacific Islands are absent in the subtropical islands. Many species-rich Indo-Malaysian genera are reduced to few or no species in the subtropics. A number of plant cultigens, including breadfruit (Artocarpus altilis, Moraceae), are currently absent on many of the subtropical islands, but may have been present in the past. This attenuation probably follows a reduction in geological diversity, as all islands are volcanic and, with the exception of northern New Zealand, are entirely oceanic in origin. The climates of the subtropical Polynesian islands are influenced by the $23 \mathrm{C}$ summer isotherm (Figure 1), marking the approximate southern limit of surface coral growth, and the decreasing sea surface winter isotherms (Figure 1) that incline from the west to the east

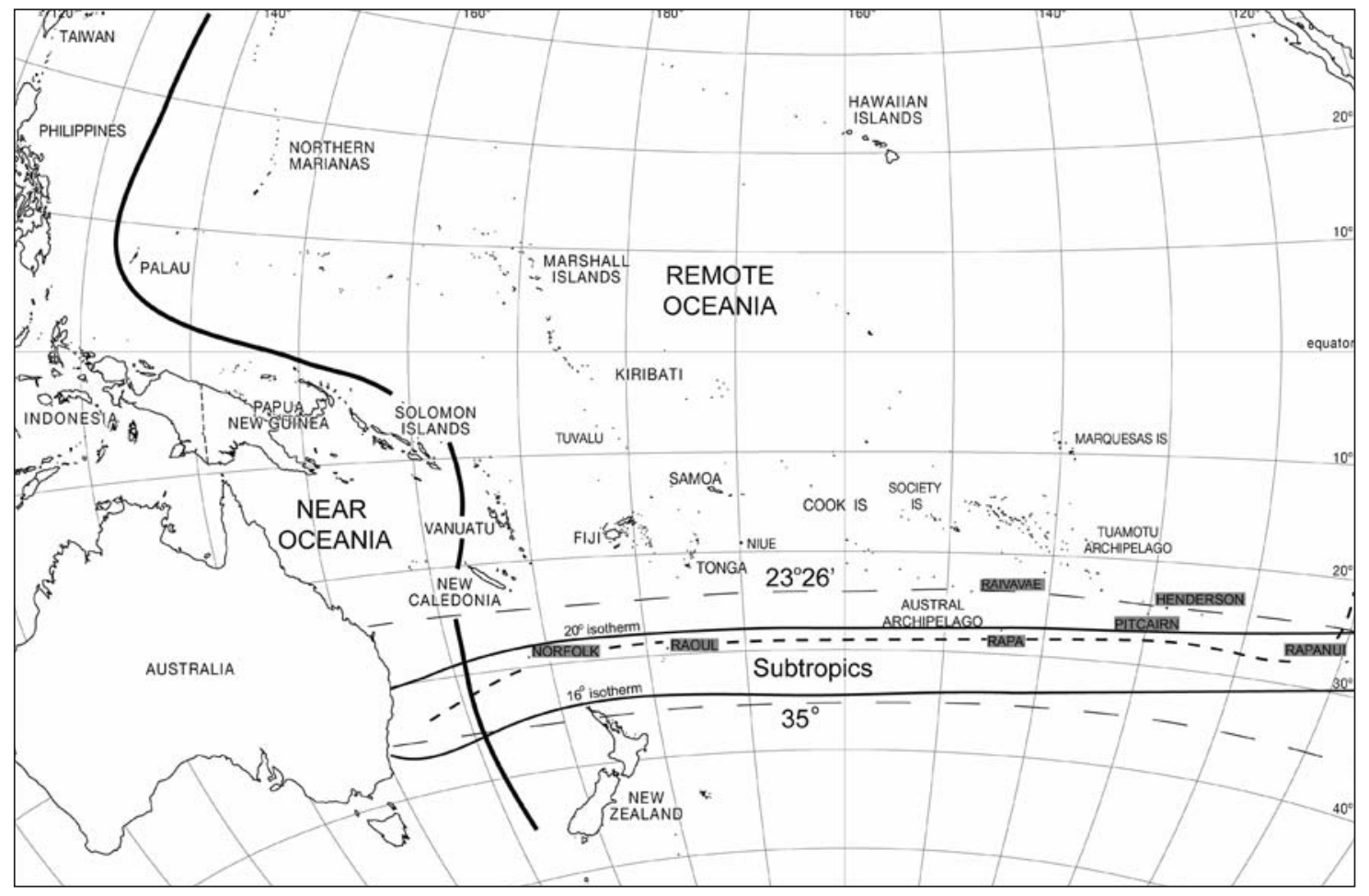

Figure 1. Map of the Pacific: the division between Near and Remote 0ceania, the subtropics between $23^{\circ} 26^{\prime} 22^{\prime \prime} \mathrm{S}$ and $35^{\circ} \mathrm{S}$, showing the main archipelagos and the subtropical Polynesian islands (shaded labels). Sea-surface winter isotherms (20 and 16C; thick black lines) and the summer isotherm (23C, dashed black line), marking the approximate southern margin of surface coral growth. 
Table 1. The subtropical islands of Remote Oceania colonised by Polynesians before European contact. Listed are the main geographic and climatic characteristics of each island.

\begin{tabular}{|c|c|c|c|c|c|c|c|}
\hline $\begin{array}{l}\text { Island } \\
\text { (Sovereign) }\end{array}$ & $\begin{array}{l}\text { Latitude / } \\
\text { Longitude }\end{array}$ & $\begin{array}{l}\text { Area } \\
\left(\mathrm{km}^{2}\right)\end{array}$ & $\begin{array}{l}\text { Highest } \\
\text { elevation (m) }\end{array}$ & $\begin{array}{l}\text { Temperature range } \\
\left({ }^{\circ} \mathrm{C}\right) / \min \text { and } \max \\
\text { recorded temp }\left({ }^{\circ} \mathrm{C}\right)\end{array}$ & $\begin{array}{l}\text { Mean annual } \\
\text { rainfall }(\mathrm{mm})\end{array}$ & $\begin{array}{l}\text { No. vascular } \\
\text { plants (no. } \\
\text { endemics) }\end{array}$ & Reference \\
\hline $\begin{array}{l}\text { Raivavae } \\
\text { (French Polynesia) }\end{array}$ & $\begin{array}{l}23^{\circ} 52^{\prime} \mathrm{S} / \\
147^{\circ} 39^{\prime} \mathrm{W}\end{array}$ & 20.3 & 437 & $?$ & $?$ & $147(43)$ & Meyer (unpublished) \\
\hline $\begin{array}{l}\text { Henderson* } \\
\text { (United Kingdom) }\end{array}$ & $\begin{array}{l}24^{\circ} 22^{\prime} \mathrm{S} / \\
128^{\circ} 18^{\prime} \mathrm{W}\end{array}$ & 37.2 & 33 & $\begin{array}{l}16-24 \text { (Winter) } \\
22-30 \text { (Summer) }\end{array}$ & 1623 & $54(9)$ & Florence et al. (1995) \\
\hline $\begin{array}{l}\text { Pitcairn* } \\
\text { (United Kingdom) }\end{array}$ & $\begin{array}{l}25^{\circ} 04^{\prime} \mathrm{S} / \\
130^{\circ} 06^{\prime} \mathrm{W}\end{array}$ & 4.6 & 347 & $\begin{array}{l}\text { 13-23 (Winter) } \\
17-28 \text { (Summer) }\end{array}$ & 1716 & $57(9)$ & Florence et al. (1995) \\
\hline Rapanui (Chile) & $\begin{array}{l}27^{\circ} 09^{\prime} \mathrm{S} / \\
109^{\circ} 6^{\prime} \mathrm{W}\end{array}$ & 166 & 511 & $\begin{array}{l}\text { 14-22 (Winter) } \\
15-28 \text { (Summer) }\end{array}$ & 1365 & $43(4)$ & Zizka (1991) \\
\hline Rapa (French Polynesia) & $\begin{array}{l}27^{\circ} 36^{\prime} \mathrm{S} / \\
144^{\circ} 20^{\prime} \mathrm{W}\end{array}$ & 38 & 631 & $\begin{array}{l}16-21 \text { (Winter) } \\
22-26 \text { (Summer) }\end{array}$ & 2664 & $212(79)$ & $\begin{array}{l}\text { Rapa Meteo (unpublished } \\
\text { data); Meyer (2002), } \\
\text { Motley (unpublished) }\end{array}$ \\
\hline Norfolk* (Australia) & $\begin{array}{l}29^{\circ} 02^{\prime} \mathrm{S} / \\
167^{\circ} 56^{\prime} \mathrm{E}\end{array}$ & 34.6 & 316 & $\begin{array}{l}\text { 13-19 (Winter) } \\
18-25 \text { (Summer) }\end{array}$ & 1312 & $345(149)$ & $\begin{array}{l}\text { www.bom.gov.au; } \\
\text { Green (1994) }\end{array}$ \\
\hline 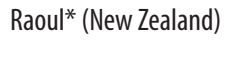 & $\begin{array}{l}29^{\circ} 15^{\prime} \mathrm{S} / \\
177^{\circ} 55^{\prime} \mathrm{W}\end{array}$ & 29.38 & 516 & $16-22$ & 1554 & $104(6 ?)$ & Sykes (1977) \\
\hline
\end{tabular}

* Islands abandoned by Polynesians before European contact. Rapanui and Rapa continuously occupied. Islands abandoned by Polynesians prior to European contact. It is assumed that Raivavae, Rapanui, Rapa and subtropical northern New Zealand have been continuously occupied since initial colonisation.

Table 2. First-European-contact accounts for the subtropical Polynesian islands and the main floral compendium for each island.

\begin{tabular}{|c|c|c|c|c|c|}
\hline Island & $\begin{array}{l}\text { Polynesian } \\
\text { colonisation } \\
\text { chronology }\end{array}$ & First European contact & $\begin{array}{l}\text { First comprehensive } \\
\text { floral compendium }\end{array}$ & $\begin{array}{l}\text { Most recent floral } \\
\text { compendium }\end{array}$ & References \\
\hline Raivavae & $700 \mathrm{BP}$ & 1775 Aguila, Jupiter & 1921-1934 & 2002 & $\begin{array}{l}\text { Corney (1913-1919); St. John and Fosberg } \\
\text { (1934); Meyer (unpublished) }\end{array}$ \\
\hline Henderson & $600 \mathrm{BP}$ & $\begin{array}{l}1606 \text { San Pedro y San Pablo, } \\
\text { San Pedro and Los Tres Reyes }\end{array}$ & 1962 & 1995 & $\begin{array}{l}\text { Weisler (1995); St. John and Philipson } \\
\text { (1962); Fosberg et al. (1983); Florence et } \\
\text { al. (1995). }\end{array}$ \\
\hline Pitcairn & $600 \mathrm{BP}$ & 1767 HMS Swallow & 1987 & 1995 & $\begin{array}{l}\text { St. John (1978); Florence et al. (1995); } \\
\text { Weisler (1996) }\end{array}$ \\
\hline Rapanui & $700 \mathrm{BP}$ & $\begin{array}{l}1721 \text { Arend, Tienhoven and } \\
\text { De Afrikaansche Galey }\end{array}$ & 1917 & 1991 & $\begin{array}{l}\text { Corney (1913-1919); Skottsberg } \\
\text { (1920-1956); Zizka (1991); Hunt and Lipo } \\
(2006)\end{array}$ \\
\hline Rapa & $700 \mathrm{BP}$ & 1791 HMS Discovery & 1921-1934 & $2002-2004$ & $\begin{array}{l}\text { Vancouver (1803); St. John and Fosberg } \\
\text { (1934); Shineberg (1986); Meyer et al. } \\
\text { 2004); Kennett et al. (2006) }\end{array}$ \\
\hline Norfolk & $500 \mathrm{BP}$ & 1774 HMS Resolution & 1804-1805 & 1963-1985 & $\begin{array}{l}\text { Endlicher (1833); Hoare (1987); Anderson } \\
\text { et al. (2001); Green (1994) }\end{array}$ \\
\hline Raoul & $700 \mathrm{BP}$ & $\begin{array}{l}1793 \text { La Recherche and } \\
\text { d'Hesmity-d'Auribeau }\end{array}$ & 1854 & 1977 & $\begin{array}{l}\text { Hooker (1856); Sykes (1977); Anderson } \\
\text { (1980); Higham and Johnson (1996) }\end{array}$ \\
\hline
\end{tabular}


Pacific. Such climatic gradients are likely to influence plant dispersal, the distribution of animal dispersers and plant establishment and recruitment on subtropical Pacific Islands.

\section{The introduced floras of the subtropical Polynesian islands}

Of the subtropical Polynesian islands, pre-contact introduced plants are best known for Rapanui, Rapa and New Zealand, largely because first European contact records of these islands are available and these islands were inhabited at contact, unlike Henderson, Pitcairn, Norfolk and Raoul. The availability of rich late-Holocene palaeobotanical deposits from these islands is important for defining pre-contact introductions, especially weeds, but these data thus far are only available for Rapa (e.g. Kennett et al. 2006), Norfolk (MacPhail 2001) and Rapanui (e.g. Flenley et al. 1991). Archaeobotanical records provide useful sources of information data on economic plants and are now available for most of the subtropical Polynesian islands. Much is known about the distribution and introduction of several crops to these islands, including Colocasia esculenta (Matthews 2004), Cordyline fruticosa (Hinkle 2004), Ipomoea batatas (Green 2005) and Lagenaria siceraria (Clark et al. 2006). In this paper, I examine a number of plants introduced to the islands of subtropical Remote Oceania, focusing on those poorly known plants, but which have been discussed more broadly for Remote Oceania by a number of authors, including Guppy (1906), Ridley (1930), Merrill (1946), Barrau (1965), Yen (1973, 1974a) and Whistler (1991). Some of these taxa have an uncertain introduction status and the reasons for this uncertainty are explored. I focus on taxa represented in subtropical Polynesian island floras and described in the main floral compendiums for each island (Brown 1931, 1935; Sykes 1977; Green 1994; Florence et al. 1995; Florence 1997, 2004). Taxa are grouped in separate tables for trees and shrubs (Table $3 \mathrm{a}$ and $3 \mathrm{~b}$ ), herbs (Table 4) and inadvertent introductions (Table 5). Each table is divided into the following categories of presence/absence data: pre-human palaeobotanical records; archaeobotanical records; anthropogenic palaeobotanical records; and botanical survey records.

As the availability of botanical information for each taxon varies considerably, with no one taxon having a complete record (i.e. some taxa have no palaeobotanical record and have only been recorded in modern botanical surveys), I focus on taxa that reflect the variation of available palaeobotanical, archaeobotanical and botanical survey data.

\section{Probable intentional tree and shrub introductions}

A number of tree and shrub taxa sometimes regarded as indigenous to subtropical Polynesian islands appear to survive only in cultivation (e.g. Cocos nucifera and Thespesia populnea). Others appear to have become naturalised from cultivated populations (e.g. Cordyline fruticosa). For some taxa, the introduced and cultivation status is clear, given the lack of sexual reproductive traits whereby plants are reliant on human propagation of vegetative clones. For example, in Broussonetia papyrifera, the cumulative effects of increasing mutations evident in wild and cultivated populations eventually led to vegetative propagation dependence (Matthews 1996). For other taxa, the status of indigenous plants, given the pre-human extent of their sub-fossil records, is difficult to define, given the possibility that people may have introduced additional populations or varieties (e.g. Pandanus tectorius). For many taxa, the botanical status cannot be securely given because of the lack of botanical source evidence.

\section{Pandanus tectorius Parkinson (Pandanaceae)}

Whistler (1991) earlier questioned the status of Pandanus tectorius as an introduced species to Remote Oceania. He suggested that $P$. tectorius of both Tonga and Samoa is represented by both 
Table 3a. (Anacardiaceae to Malvaceae) Botanical source list of pre-contact introduced or indigenous trees and shrubs (including known arboricultural species) for the subtropical Polynesian islands (arranged by family), recognised in the references and by Whistler (1991).

\begin{tabular}{|c|c|c|c|c|c|c|}
\hline \multirow[t]{2}{*}{ Botanical species } & \multirow{2}{*}{$\begin{array}{l}\text { Pre-human palaeo- } \\
\text { botanical records }\end{array}$} & \multirow{2}{*}{$\begin{array}{l}\text { Archaeobotanical } \\
\text { records }\end{array}$} & \multirow{2}{*}{$\begin{array}{l}\text { Anthropogenic } \\
\text { palaeobotanical } \\
\text { records }\end{array}$} & \multirow{2}{*}{$\begin{array}{l}\text { First contact } \\
\text { accounts } \\
1606-1793\end{array}$} & \multicolumn{2}{|c|}{ Botanical survey data } \\
\hline & & & & & $\begin{array}{l}\text { Earliest flora } \\
\text { compendium }\end{array}$ & $\begin{array}{l}\text { Recent flora } \\
\text { compendium }\end{array}$ \\
\hline $\begin{array}{l}\text { Alyxia stellata (J.R. Forst. } \\
\text { and G. Forst.) Roem. and } \\
\text { Schult. (Apocynaceae)2 }\end{array}$ & - & - & - & - & $\begin{array}{l}\text { Raivavae, } \\
\text { Henderson (?), } \\
\text { Rapa }\end{array}$ & $\begin{array}{l}\text { Raivavae, Henderson } \\
\text { (?) }\end{array}$ \\
\hline $\begin{array}{l}\text { Cocos nucifera L. (Arecaeceae: } \\
\text { (ocoeae) }{ }^{1}\end{array}$ & - & - & - & $\begin{array}{l}\text { Rapa } \\
\text { (introduced)? }\end{array}$ & $\begin{array}{l}\text { Raivavae, } \\
\text { Henderson, } \\
\text { Rapanui, Rapa }\end{array}$ & $\begin{array}{l}\text { Raivavae, Henderson, } \\
\text { Rapanui, Rapa, } \\
\text { Raoull12 }\end{array}$ \\
\hline $\begin{array}{l}\text { Barringtonia asiatica L. } \\
\text { Kurz (Barringtoniaceae) }\end{array}$ & - & - & - & - & Raivavae, Pitcairn & Raivavae, Pitcairn \\
\hline $\begin{array}{l}\text { Cordia subcordata Lam. } \\
\text { (Boraginaceae) })^{9}\end{array}$ & - & - & - & - & - & Henderson \\
\hline $\begin{array}{l}\text { Casuarina equisetifolia L. } \\
\text { (Casuarinaceae) }^{4}\end{array}$ & $\begin{array}{l}\text { Rapanui, (pollen) }{ }^{10} \text {, } \\
\text { Rapa }(\text { pollen })^{6}\end{array}$ & - & $\begin{array}{l}\text { Rapanui, (pollen), } \\
\text { Rapa (pollen) }\end{array}$ & - & Raivavae & Raivavae, Rapa \\
\hline $\begin{array}{l}\text { Calophyllum inophyllum L. } \\
\text { (Clusiaceae) }^{4}\end{array}$ & - & - & - & - & Raivavae, Pitcairn & Raivavae, Pitcairn \\
\hline Corynocarpus laevigatus & - & - & $\begin{array}{l}\text { Raoul, Northern } \\
\text { New Zealand }\end{array}$ & & $\begin{array}{l}\text { Raoul, northern } \\
\text { New Zealand }\end{array}$ & $\begin{array}{l}\text { Raoul, northern } \\
\text { New Zealand }\end{array}$ \\
\hline $\begin{array}{l}\text { Terminalia catappa L. } \\
\text { (Combretaceae) })^{2}\end{array}$ & - & - & - & - & Raivavae & Raivavae \\
\hline $\begin{array}{l}\text { Aleurites moluccana L. } \\
\text { Willd. (Euphorbiaceae) }\end{array}$ & - & $\begin{array}{l}\text { Rapa (endocarp) } \\
\text { Raoul (endocarp) }\end{array}$ & Rapa (pollen) ${ }^{6}$ & Rapanui? & $\begin{array}{l}\text { Raivavae, } \\
\text { Henderson, } \\
\text { Pitcairn, Rapa, } \\
\text { Raoul }\end{array}$ & $\begin{array}{l}\text { Raivavae, Henderson, } \\
\text { Raoul, Rapa }\end{array}$ \\
\hline 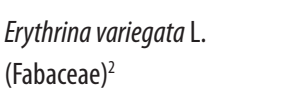 & - & - & Rapa (pollen) ${ }^{6}$ & - & $\begin{array}{l}\text { Raivavae, Pitcairn, } \\
\text { Rapa }\end{array}$ & $\begin{array}{l}\text { Raivavae, Pitcairn, } \\
\text { Rapa }\end{array}$ \\
\hline $\begin{array}{l}\text { Cordyline fruticosa L. Chev. } \\
\text { (Laxmanniaceae })^{1}\end{array}$ & $\begin{array}{l}\text { Norfolk (pollen record } \\
\text { may be of an endemic } \\
\text { species) }\end{array}$ & $\begin{array}{l}\text { Rapanui (charcoal) }{ }^{11}, \\
\text { Rapa? (charred tuber) }\end{array}$ & $\begin{array}{l}\text { Rapa (pollen) } \\
\text { Norfolk (pollen?) }\end{array}$ & $\begin{array}{l}\text { Rapanui (?), } \\
\text { Rapa }\end{array}$ & $\begin{array}{l}\text { Raivavae, } \\
\text { Rapanui, Rapa }\end{array}$ & $\begin{array}{l}\text { Raivavae, Henderson, } \\
\text { Pitcairn, } \\
\text { Rapanui, Rapa, } \\
\text { Norfolk, Raoul }\end{array}$ \\
\hline $\begin{array}{l}\text { Hibiscus tiliaceus L. } \\
\text { (Malvaceae) }{ }^{4}\end{array}$ & $\begin{array}{l}\text { Rapa (pollen) }{ }^{6}, \\
\text { Norfolk (pollen) }\end{array}$ & Rapa (fibre) $)^{5}$ & Norfolk (pollen?) ${ }^{9}$ & $\begin{array}{l}\text { Rapanui (?), } \\
\text { Rapa (?) }\end{array}$ & $\begin{array}{l}\text { Raivavae, Rapa, } \\
\text { Raoul }\end{array}$ & $\begin{array}{l}\text { Raivavae, Rapa, } \\
\text { Norfolk, Raoul }\end{array}$ \\
\hline $\begin{array}{l}\text { Thespesia populnea L. Sol. } \\
\text { Ex Correa (Malvaceae) }\end{array}$ & - & Rapanui (charcoal) ${ }^{11}$ & - & Rapa & $\begin{array}{l}\text { Raivavae, } \\
\text { Henderson, Rapa }\end{array}$ & Raivavae, Rapa \\
\hline
\end{tabular}

'Brown (1931); ${ }^{2}$ Brown (1935); ${ }^{3}$ Florence (1997); ${ }^{4}$ Florence (2004); ${ }^{5}$ Prebble and Anderson (In press); ${ }^{6}$ Prebble et al, (submitted); ${ }^{7}$ Macphail et al. (2001); ${ }^{8}$ Anderson (unpublished); ${ }^{9}$ Macphail et al. (2001); ${ }^{10}$ Flenley (1991); ${ }^{11} \mathrm{Orliac}(1998) ;{ }^{12}$ Sykes and West (1996). 
Table 3b. (Moraceae to Urticaceae) Botanical source list of pre-contact introduced or indigenous trees and shrubs (including known arboricultural species) for the subtropical Polynesian islands (arranged by family), recognised in the references and by Whistler (1991).

\begin{tabular}{|c|c|c|c|c|c|c|}
\hline \multirow[t]{2}{*}{ Botanical species } & \multirow{2}{*}{$\begin{array}{l}\text { Prehuman palaeo- } \\
\text { botanical records }\end{array}$} & \multirow{2}{*}{$\begin{array}{l}\text { Archaeobotanical } \\
\text { records }\end{array}$} & \multirow{2}{*}{$\begin{array}{l}\text { Anthropogenic } \\
\text { palaeobotanical } \\
\text { records }\end{array}$} & \multirow{2}{*}{$\begin{array}{l}\text { First European } \\
\text { contact } \\
\text { accounts } \\
1606-1793\end{array}$} & \multicolumn{2}{|c|}{ Botanical survey data } \\
\hline & & & & & $\begin{array}{l}\text { Earliest } \\
\text { compendium }\end{array}$ & $\begin{array}{l}\text { Latest } \\
\text { compendium }\end{array}$ \\
\hline $\begin{array}{l}\text { Artocarpus altilis Parkinson } \\
\text { (Fosberg) (Moraceae) }^{3}\end{array}$ & - & - & - & - & Raivavae, Rapa & Raivavae \\
\hline $\begin{array}{l}\text { Broussonetia papyrifera } \\
\text { L. Vent. (Moraceae) }\end{array}$ & - & Rapanui (charcoal) & - & $\begin{array}{l}\text { Rapanui (?), New } \\
\text { Zealand }\end{array}$ & $\begin{array}{l}\text { Raivavae, Rapa, } \\
\text { New Zealand }\end{array}$ & $\begin{array}{l}\text { Raivavae, Rapa, } \\
\text { New Zealand }\end{array}$ \\
\hline $\begin{array}{l}\text { Ficus tinctoria Forst. subsp. } \\
\text { tinctoria (Moraceae) }\end{array}$ & - & - & Rapa (pollen)? & Rapanui (?) & Raivavae, Rapa & Raivavae, Rapa \\
\hline $\begin{array}{l}\text { Musa spp. (AAB group) [syn. M. } \\
\text { x paradaisica, M. sapientum] } \\
\text { (Musaceae: section Eumusa) }^{1}\end{array}$ & - & - & - & $\begin{array}{l}\text { Rapanui, Rapa, } \\
\text { Norfolk }^{6}\end{array}$ & $\begin{array}{l}\text { Raivavae (?), Rapa, } \\
\text { Rapanui }\end{array}$ & $\begin{array}{l}\text { Raivavae, Rapa, } \\
\text { Rapanui }\end{array}$ \\
\hline $\begin{array}{l}\text { Musa spp. [syn. M. fehi, M. } \\
\text { troglodytarum, M. balbisiana] } \\
\text { (Musaceae: section Australimusa } \\
\text { and Callimusa) } \text { ) }^{1,3}\end{array}$ & - & - & - & $\begin{array}{l}\text { Rapa } \\
\text { (introduced?) }\end{array}$ & Raivavae, Rapa & Raivavae, Rapa \\
\hline $\begin{array}{l}\text { Musa spp. (AAA group) [M. } \\
\text { acuminata, M. nana, M. sinensis] } \\
\text { (Musaceae: section Eumusa) }^{1}\end{array}$ & - & - & - & - & Raivavae (?), Rapa & $\begin{array}{l}\text { Raivavae, Rapa }{ }^{4} \text {, } \\
\text { Raoul }\end{array}$ \\
\hline $\begin{array}{l}\text { Syzygium malaccense L. Merrill } \\
\text { and Perry (Myrtaceae)2 }\end{array}$ & - & Rapanui (charcoal) & Rapa (pollen)? & - & Raivavae, Rapa & Raivavae, Rapa \\
\hline $\begin{array}{l}\text { Pandanus tectorius Parkinson } \\
\text { (Pandanaceae) }^{6}\end{array}$ & Rapa (pollen) & $\begin{array}{l}\text { Rapa (pollen, } \\
\text { syncarp) }\end{array}$ & $\begin{array}{l}\text { Henderson (pollen), } \\
\text { Pitcairn (pollen), } \\
\text { Rapa (pollen) }\end{array}$ & Rapa & $\begin{array}{l}\text { Raivavae, } \\
\text { Henderson, } \\
\text { Pitcairn, Rapa }\end{array}$ & $\begin{array}{l}\text { Raivavae, } \\
\text { Henderson, } \\
\text { Pitcairn, Rapa }\end{array}$ \\
\hline $\begin{array}{l}\text { Sapindus saponaria L. } \\
\text { (Sapindaceae) }^{4}\end{array}$ & - & - & - & Rapanui & Rapanui & Pitcairn, Rapanui \\
\hline $\begin{array}{l}\text { Solanum viride Forst. f. ex Spring } \\
\text { (Solanaceae) })^{5}\end{array}$ & - & - & - & - & $?$ & Rapa \\
\hline
\end{tabular}

'Brown (1931a); ${ }^{2}$ Brown (1935); ${ }^{3}$ Florence (1997); ${ }^{4}$ Zizka (1991); ${ }^{5}$ Hoare (1987:12-14); ${ }^{6}$ Not all information available. 
Table 4. Botanical sources of probable herb introductions (including tuber, corn and rhizome cultigens) (arranged by family) to the subtropical Polynesian islands, recognised in the references and by Whistler (1991). None of these species have been located in any pre-human palaeobotanical record.

\begin{tabular}{|c|c|c|c|c|c|}
\hline \multirow[t]{2}{*}{ Botanical species } & \multirow{2}{*}{$\begin{array}{l}\text { Archaeobotanical } \\
\text { records }\end{array}$} & \multirow{2}{*}{$\begin{array}{l}\text { Anthropogenic } \\
\text { palaeobotanical } \\
\text { records }\end{array}$} & \multirow{2}{*}{$\begin{array}{l}\text { First-contact } \\
\text { accounts } \\
1606-1793\end{array}$} & \multicolumn{2}{|c|}{ Botanical survey data for Rapa } \\
\hline & & & & Earliest compendium & Latest compendium \\
\hline Alocasia macrorrhiza L. (Araceae) & Pitcairn (pollen) ${ }^{7}$ & - & Rapa? & Raivavae, Rapa & Raivavae, Rapa \\
\hline $\begin{array}{l}\text { Colocasia esculenta L. Schott. } \\
\text { (Araceae) }^{1}\end{array}$ & Rapa? (tuber peelings) ${ }^{4}$ & Rapa (pollen) ${ }^{5}$ & $\begin{array}{l}\text { Raivavae, Rapa, } \\
\text { northern New } \\
\text { Zealand }\end{array}$ & $\begin{array}{l}\text { Raivavae, Rapanui, Rapa, } \\
\text { northern New Zealand }\end{array}$ & $\begin{array}{l}\text { Raivavae, Rapanui, Rapa, } \\
\text { Raoul, northern New } \\
\text { Zealand }\end{array}$ \\
\hline $\begin{array}{l}\text { Cyrtosperma merkusii (Haask.) } \\
\text { Schott. (syn. C. chamissonis) } \\
\text { (Araceae) }\end{array}$ & Henderson (leaf) ${ }^{6}$ & - & - & - & - \\
\hline $\begin{array}{l}\text { Ipomoea batatas L. } \\
\text { (Convovulaceae) }^{2}\end{array}$ & $\begin{array}{l}\text { Rapanui (charcoal, } \\
\text { starch) }{ }^{8} \text {, New Zealand } \\
(\text { starch })^{8}\end{array}$ & - & $\begin{array}{l}\text { Rapanui, } \\
\text { New Zealand }\end{array}$ & $\begin{array}{l}\text { Raivavae, Rapanui, Rapa, } \\
\text { New Zealand }\end{array}$ & $\begin{array}{l}\text { Raivavae, Rapa, Raoul, } \\
\text { New Zealand }\end{array}$ \\
\hline $\begin{array}{l}\text { Lagenaria siceraria (Molina) } \\
\text { Standl. (Cucurbitaceae) }\end{array}$ & $\begin{array}{l}\text { Rapa (pericarp, } \\
\text { phytoliths) }{ }^{4}, \text { New Zealand } \\
\text { (phytoliths) }^{8}\end{array}$ & - & $\begin{array}{l}\text { Rapa, northern } \\
\text { New Zealand }\end{array}$ & $\begin{array}{l}\text { Rapa, northern } \\
\text { New Zealand }\end{array}$ & $\begin{array}{l}\text { northern } \\
\text { New Zealand }\end{array}$ \\
\hline $\begin{array}{l}\text { Dioscorea spp. [D. alata, } \\
\text { D. bulbifera, D. pentaphylla, } \\
\text { D. sativa] (Dioscoreaceae) }{ }^{1}\end{array}$ & - & - & Rapa & $\begin{array}{l}\text { Raivavae (D. sativa), Rapa } \\
\text { (D. alata, D. bulbifera, D. } \\
\text { pentaphylla, D. sativa) }\end{array}$ & $\begin{array}{l}\text { Rapa (D. alata, D. bulbifera, } \\
\text { D. pentaphylla, D. sativa) }\end{array}$ \\
\hline $\begin{array}{l}\text { Manihot esculenta Crantz } \\
\text { (Euphorbiaceae) })^{3}\end{array}$ & - & - & - & Raivavae, Rapa & Raivavae, Rapa \\
\hline $\begin{array}{l}\text { Tephrosia pupurea L. Pers. } \\
\text { (Fabaceae) }\end{array}$ & - & - & - & - & Raivavae, Rapa \\
\hline $\begin{array}{l}\text { Erianthus maximus Brongn. } \\
\text { (Poaceae) }\end{array}$ & - & - & - & Rapa & Rapa \\
\hline 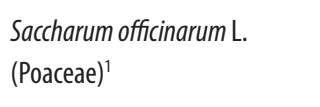 & Rapanui (charred leaf) ${ }^{8}$ & - & Rapa & Raivavae, Rapa & Raivavae, Rapa \\
\hline $\begin{array}{l}\text { Tacca leontopetaloides L. Kuntze } \\
\text { (Taccaceae) } 1\end{array}$ & - & - & - & Rapa & Rapa \\
\hline $\begin{array}{l}\text { Curcuma longa L. } \\
\text { (Zingiberaceae) }^{1}\end{array}$ & - & - & - & Raivavae, Rapa & - \\
\hline 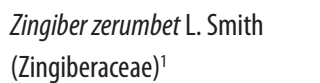 & - & - & - & Raivavae, Rapa & Raivavae, Rapa \\
\hline
\end{tabular}

'Brown (1931); 'Brown (1935); ${ }^{3}$ Florence (1997); 4 Prebble and Anderson (In press), ${ }^{5}$ Prebble et al. (submitted), ${ }^{6}$ Hather and Weisler (2000), ${ }^{7}$ Horrocks and Weisler (2006), ${ }^{8}$ tentative records from a number of sources (for Ipomoea batatas in New Zealand see Yen and Head 1993). 
Table 5. Botanical sources of probable inadvertent plant introductions (arranged by family) to the subtropical Polynesian islands, recognised in the references and by Whistler (1991). None of these species have been located in any prehuman palaeobotanical or first-contact record.

\begin{tabular}{|c|c|c|c|}
\hline \multirow[t]{2}{*}{ Botanical species } & \multirow{2}{*}{$\begin{array}{l}\text { Anthropogenic palaeobotanical } \\
\text { records }\end{array}$} & \multicolumn{2}{|l|}{ Botanical survey data } \\
\hline & & Earliest compendium & Latest compendium \\
\hline $\begin{array}{l}\text { Achyranthes aspera var. aspera L. } \\
\text { (Amaranthaceae) })^{3,6}\end{array}$ & $\begin{array}{l}\text { Probable prehuman Achyranthes } \\
\text { record on Norfolk, but may represent } \\
\text { an endemic species }{ }^{9}\end{array}$ & Raivavae & Raivavae, Pitcairn, Rapa, Norfolk, Raoul \\
\hline Amaranthus viridis L. (Amaranthaceae) $)^{3}$ & Rapa (pollen?) Raoul (pollen?) ${ }^{8}$ & Raivavae, Rapa & Raivavae, Pitcairn, Rapa \\
\hline Bidens pilosa L. (Asteraceae) ${ }^{6}$ & Rapa (pollen?) $)^{7}$ & Raivavae, Rapa & $\begin{array}{l}\text { Raivavae, Pitcairn, Rapa, Norfolk, Raoul, } \\
\text { northern New Zealand }\end{array}$ \\
\hline Sigesbeckia orientalis L. (Asteraceae) ${ }^{6}$ & Raoul (pollen?) ${ }^{7}$ & $\begin{array}{l}\text { Raivavae, Rapa, Raoul, } \\
\text { northern New Zealand }\end{array}$ & $\begin{array}{l}\text { Raivavae, Pitcairn, Rapa, Norfolk, } \\
\text { northern New Zealand }\end{array}$ \\
\hline Sonchus oleraceus L. (Asteraceae) $)^{2}$ & Rapa (pollen)7, Raoul (pollen?) ${ }^{8}$ & Raivavae, Rapa & $\begin{array}{l}\text { Raivavae, Pitcairn, Rapanui, Rapa, } \\
\text { Norfolk }\end{array}$ \\
\hline Canna indica L. (Cannaceae) $)^{2}$ & - & Raivavae, Rapa & Raivavae, Pitcairn, Rapa, Norfolk, Raoul \\
\hline Commelina diffusa Burm. f. (Commelinaceae) ${ }^{2}$ & Rapa (pollen) ${ }^{7}$ & Raivavae, Rapa & Raivavae, Pitcairn, Rapanui, Rapa \\
\hline Sida rhombifolia L. (Malvaceae) $)^{3,5}$ & - & Raivavae, Rapa & Raivavae, Rapanui, Rapa, Norfolk, Raoul \\
\hline $\begin{array}{l}\text { Ludwigia octovalvis (Jacq.) Raven } \\
\text { (Onagraceae) })^{2,4}\end{array}$ & Rapa (pollen, seeds) $)^{7}$ & Raivavae, Rapa & Raivavae, Rapa \\
\hline Oxalis corniculata L. (0xalidaceae) ${ }^{4,6}$ & $(\text { Rapa, seeds? })^{7}$ & $\begin{array}{l}\text { Raivavae, Rapa, Raoul, } \\
\text { northern New Zealand }\end{array}$ & $\begin{array}{l}\text { Raivavae, Norfolk, Raoul, } \\
\text { northern New Zealand }\end{array}$ \\
\hline Eleusine indica (L.) J. Gaertner (Poaceae) $)^{1-6}$ & - & Raivavae, Rapanui, Rapa, Raoul & $\begin{array}{l}\text { Raivavae, Pitcairn, Rapanui, Rapa, } \\
\text { Norfolk, Raoul }\end{array}$ \\
\hline Oplismenus compositus, O. hirtellus (Poaceae) ${ }^{11}$ & - & Raivavae, Rapanui, Rapa & Raivavae, Pitcairn, Rapanui, Rapa \\
\hline Paspalum conjugatum, P. orbiculare (Poaceae) $)^{11}$ & - & Raivavae, Rapanui, Rapa & Raivavae, Pitcairn, Rapanui, Rapa \\
\hline $\begin{array}{l}\text { Thuarea involuta (G. Forst.) R. brown ex J. } \\
\text { Roemer and J.A. Schultes (Poaceae) }{ }^{10}\end{array}$ & - & - & Henderson (?) \\
\hline Sapindus saponaria L. (Sapindaceae) ${ }^{4}$ & - & Rapanui & Rapanui, Pitcairn \\
\hline $\begin{array}{l}\text { Rorippa sarmentosa (G.Forst. ex DC.) J.F. Macbr. } \\
\text { (Solanaceae) })^{4,6}\end{array}$ & - & Rapanui & Rapa \\
\hline Solanum americanum P. Mill (Solanaceae) & Rapa (pollen ?, seeds) ${ }^{7}$, Raoul (pollen?) ${ }^{8}$ & $\begin{array}{l}\text { Raivavae, Rapa, northern New } \\
\text { Zealand }\end{array}$ & $\begin{array}{l}\text { Raivavae, Henderson, Pitcairn, Rapa, } \\
\text { Norfolk, Raoul, northern New Zealand }\end{array}$ \\
\hline
\end{tabular}

'Brown (1931a); 'Brown (1935); '3Florence (2004); ' ZZizka (1991); '5listed in St. John (1978) from Daniel Nelson's records of possible inadvertent pre-contact introductions to

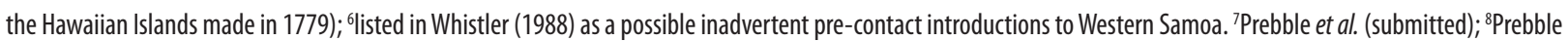
and Wilmshurst (nd); ${ }^{9}$ MacPhail et al. (2001); ${ }^{10}$ Florence et al. (1995); ${ }^{11}$ Not all information available, probable European introductions. 
indigenous and introduced populations, but queried the indigenous status of Pandanus on the Cook, Society, Marquesas, and Hawaiian Islands. High concentrations of Pandanus pollen from Holocene-aged sediments on Rapa (macrofossils also present) establish its indigenous status there, and presumably across the Austral Archipelago (Prebble 2006; Prebble et al. submitted). With the unequivocal subfossil evidence, it is interesting that no reference was made to the palm-like Pandanus tectorius trees at first European contact. Pandanus was often noted as 'screw palm' or 'palm apple', as described by Morrison (1935:61) on Tubuai, to the north of Rapa, in the botanical vernacular of early European explorers. While immediately offshore from Rapa on the HMS Discovery in 1791, Menzies (in Shineberg 1986:67) mentioned Dracena leaves, which probably refers to Pandanus, in reference to a girdle should be suspened around the waist of one of the islanders, but this determination remains unclear.

Both leaf material and fruit keys from Pandanus have been identified from the Tangarutu rock-shelter sequence on Rapa, with an earliest inferred radiocarbon age of about $500 \mathrm{cal}$. BP (Prebble 2006; Prebble and Anderson In press). Horrocks and Weisler (2006) identified Pandanus pollen from archaeological sediments from both Pitcairn and Henderson, dated to c. $600 \mathrm{cal}$. BP and $800 \mathrm{cal}$. BP respectively. The archaeobotanical and palaeobotanical evidence, however, does not rule out the possibility, suggested by Whistler (1991), that additional varieties of Pandanus tectorius were introduced pre-contact. Pandanus is a dioecious genus with extreme morphological diversity that can be considerably influenced by cultivation practices. This has resulted in a number of inconsistent taxonomic determinations of members of this genus (see Stone 1976, 1988; St. John 1976, 1979). St. John (in Fosberg and St. John 1934) identified 13 endemic species of Pandanus on Rapa alone. Most of these species have subsequently been grouped into Pandanus tectorius and one other species has yet to be described (Tim Motley and Jaques Florence pers comm. 2004).

As yet, no phylogenetic studies have been undertaken for Pandanus tectorius. Such studies might yet distinguish different intraspecific populations. The morphological diversity in Pandanus that St. John identified on Rapa may be a result of genetic or environmental processes, but may also reflect the introduction of cultivated varieties by islanders both pre and post contact. The ethnobotanical importance of Pandanus on Rapa (e.g. Stokes ms), attested by the archaeobotanical record, but also from first-contact and ethnographic sources, highlights the potential for additional introductions. The indigenous status of Pandanus is only unequivocal from Rapa, but it is probably also indigenous to Henderson and Pitcairn. The human introduction of particular cultivars cannot be discounted as a factor in the current population distribution of this tree.

\section{Casuarina equisetifolia L. (Casuarinaceae)}

Florence (2004) determined C. equisetifolia subsp. equisetifolia from modern populations on Rapa. He suggests its distribution is problematic because of its wind-dispersed seeds and possible extension by human introduction to many islands of the Pacific. It was likely to have been introduced to Rapa in the historic period or earlier, but is probably indigenous to the northern islands of the Austral Archipelago. Whistler (1991) suggests that the distribution of C. equisetifolia in the east-Polynesian Pacific is a result of human introduction. This tree is represented in large stands across the Austral Archipelago, including on the atoll of Maria. On Rapa, its distribution is limited to small littoral stands on many of the least exposed bays or persistence in remnant cultivations (e.g. Anarua Bay).

The palynological record is important when discussing the status of this tree on Rapa and Rapanui. Casuarina pollen is represented throughout a Holocene swamp record on Rapa 
(Tukou) where it is only ever represented in trace counts. This is more likely to represent either contamination from modern airborne Casuarina pollen, or long-distance wind transport from the western Pacific (Close et al. 1978). At Maunutu on Rimatara, palynological records of Casuarina show a marked increase in representation within the past $1000 \mathrm{cal}$. BP (Prebble and Wilmshurst In press). This rise in pollen abundance is indicative of local pollen production and dispersal and is unequivocally associated with increases in a range of human-impact indicators (e.g. Colocasia esculenta pollen and charcoal particle concentrations).

It is difficult to determine the indigenous status of Casuarina for the subtropical Polynesian islands, given its vagility and affinity within secondary habitats (Florence 2004). From the palynological records from Rapa (Prebble 2006; Prebble et al. submitted) and Rapanui (Flenley et al. 1991) it is possible that Casuarina was originally present and then subsequently proliferated on Rapa and was extripated on Rapanui with the advent of human settlement and environmental disturbance. Florence (2004) has tentatively given C. equisetifolia subsp. equisetifolia the status of naturalised or indigenous for all of the islands of the Austral Archipelgo except Rapa. Casuarina was not recorded by Fosberg and St. John (1934) on Rapa and since their 1934 survey, this tree has become naturalised after human introduction or from beach drift.

\section{Aleurites moluccana (L.) Willdenow (Euphorbiaceae)}

The tough endocarps of Aleurites moluccana have been excavated from numerous Polynesian archaeological sites dating from early to late settlement. There is an abundance of preserved endocarps in the archaeobotanical record from Rapa (Prebble 2006; Prebble and Anderson In press) and Henderson (Weisler 1997), but this tree was not listed in any first-contact accounts of Rapa and was not recorded until the pearl trader and amateur naturalist Jacques Moerenhout (1837:64) visited there in 1834. On Henderson, A. moluccana was not recorded until 1912 and then again in 1922 (St. John and Philipson 1962; Paulay and Spencer 1989), and is currently absent (Florence et al. 1995). A. moluccana has been recorded from four localities on Raoul, and a number of authors have suggested it was indigenous to Raoul (e.g. Cheeseman 1888), although this was doubted by Oliver (1910) and later Sykes (1977), who suggest it may have been introduced by Polynesians. Johnson (1995) noted a distinct 10-30 cm band of 'melanized soil' and artefacts which may represent historic settlement. Higham and Johnson (1996) radiocarbon-dated a fragment of $A$. moluccana excavated from this melanized palaeosol, yielding a modern age. Although it was located alongside artefacts characteristic of Polynesian settlement, the site may be disturbed, and thus it may represent either an early or historic introduction.

On Rapa, Stokes (ms) noted the use of A. moluccana wood for the construction of canoes, and the nuts for lighting. From visits to Rapa in the 1920s and 1930s, both Stokes (ms) and Fosberg (Mueller-Dombois and Fosberg 1998:403) considered A. moluccana a major component of moist forests on Rapa. Robinson (1957) noted the use of A. moluccana candlenuts as the major source of night lighting on his visit to the island in 1952. Despite its importance only 50 years ago, few trees currently exist on the island. Some trees are located precariously on the margins of coastal plains or in a few localities around the major settlements of Ha' urei and Area, where the nuts provide fodder for pigs.

It is likely that until recently, $A$. moluccana formed a major component of lowland forests across most of the Austral Archipelago and the Gambiers. Tomás Gayangos (in Corney 1913-1919:126) recorded the presence of A. moluccana on Ra'ivavae in 1775, describing it as 'Tutuy'. With the exception of the larger high islands of the Fijian archipelago and the Hawaiian Islands, where $A$. moluccana forms a conspicuous component of mesic vegetation from low to 
mid elevations (Smith 1981; Wagner et al. 1999), the tree may require human maintenance and protection from browsing animals. On some islands, such as Henderson Island, the tree has been recorded in the past but is noted more recently as absent (Paulay and Spencer 1989).

Aleurites pollen has been located in anthropogenic stratified sedimentary deposits from Tukou, Rapa, dated to about 500-600 BP (Prebble et al. submitted). Other records of this kind have been located elsewhere in Remote Oceania, including Maunutu on Rimatara (Prebble and Wilmshurst In press), O'ahu in the Hawaiian Islands (e.g. Athens and Ward 1997) and Lahakai on Manus Island in Papua New Guinea (Southern 1988). In each case, Aleurites pollen is associated with Colocasia pollen and other agricultural indicators. In addition to this list are records from Hawai'i in Athens et al. (1997) and Moloka'i in Denham et al. (1999), in which A. moluccana is one of the primary agricultural indicators. Clark and Cole (1997) also identified A. moluccana pollen in sediments from Totoya Island in Fiji, but not in contexts associated with other potential cultigens. Athens and Ward (1997) located A. moluccana endocarp and wood from a sediment core at Maunawili, O'ahu, associated with Colocasia pollen and other agricultural indicators. Such records suggest $A$. moluccana is in some way associated with cultivation activity. I would suggest that, on the basis of this cultivation site association, $A$. moluccana has been dispersed beyond its indigenous range and either maintained in cultivation or become naturalised on the island.

\section{Cocos nucifera L. (Arecaceae)}

Cocos nucifera has been found throughout the humid tropical Pacific in both wild and cultivated populations on atolls, high islands and the coastlines of the peripheral continents, from sea level to elevations of c. $1000 \mathrm{~m}$ (Harries et al. 2004). The extent of natural dispersal of C. nucifera over long distances by floating coconuts has been widely debated and is largely unresolved (Ward and Brookfield 1992). Harries et al. (2004) suggest the wild type $C$. nucifera evolved by floating between areas that fringe larger landmasses and islands.

The status of $C$. nucifera has been debated for Remote Oceania at least since the Enlightenment voyages. Merrill (1946:34) suggested coconut 'normally occurs only where it has been planted by man' and said it is likely to have an Indo-Pacific origin. Fosberg (1960) regarded C. nucifera as a cultivated species, domesticated in some tropical region where its wild relatives are presumably extinct. Sauer (1971) favoured the view that coconut populations may be wild and a product of natural dispersal. Harries (1990) distinguished the morphological differences (fruit component analysis) between wild and domesticated $C$. nucifera and proposed the IndoMalayan region as the centre of domestication. The use of molecular markers such as RFLP (e.g. Lebrun et al. 1999) and AFLP (e.g. Teulat et al. 2000) generally support the conclusions of Harries' morphological analysis.

Arguments for the natural dispersal of C. nucifera in Remote Oceania (e.g. Ward and Brookfield 1992) were to some degree confirmed by excavation of $C$. nucifera endocarp from Anawau Swamp on Aneityum in Vanuatu (Spriggs 1984), dated to 6410-5950 cal. BP. This provided the first radiocarbon age outside the expected age range for human occupation of a site in Remote Oceania. Palynological records from Atiu (Parkes 1997) and Mangaia (e.g. Kirch et al. 1992; Ellison 1994) in the Cook Islands indicate a prehuman presence of C. nucifera in this part of Remote Oceania. A number of palynological records from the Hawaiian Islands (e.g. Athens and Ward 1997; Denham et al. 1999) suggest C. nucifera may have been introduced, given the presence of pollen only in anthropogenic sediment horizons.

The presence of coconut trees on Rapa presents an interesting case in the debate on the 
natural vagility and human translocation. No palaeobotanical evidence for indigenous $C$. nucifera in subtropical Polynesian islands has been forthcoming. The C. nucifera pollen record from Rimatara indicates this tree may have been recently introduced to the island, given its representation in sediments dating to the post-European contact period. C. nucifera was noted in the early European contact accounts for Ra'ivavae, Tubuai and Rurutu, but not for Rapa and Rimatara. On the HMS Discovery sighting of Rapa in 1791, both George Vancouver and his ship's botanist, Archibald Menzies, 'observed no Cocoa Nut Trees anywhere on the Island' (Shineberg 1986:67-68). Vancouver chose not to circumnavigate the island, nor venture much closer than a league (c. $4.5 \mathrm{~km}$ ). No landfall was made and the ship was only anchored for one day along the west coast of the island. In all the European contact accounts recorded to 1834 on Ra'ivavae, only Tomás Gayangos recorded C. nucifera (in Corney 1916-1919:126), in 1775. Like the HMS Discovery visit to Rapa, no landfall was made with the Aguila and the Jupiter only moored for one night. No coconut husks were observed, without which botanical determinations of early explorers tended to be misinformed. There is a possibility that the trees Gayangos observed were, in fact, another species of palm.

In 1829, the LMS missionaries, Reverends Pritchard and Simpson (1830 in Stokes ms), visited Rapa, noting that 'One coconut palm was reported as present from a drift and was not recognised by the local natives'. After his visit to Rapa in 1865, John Vine Hall ascertained from one informant that 'there were cocoa-nuts formerly on the Island, but blight destroyed them all some years ago' (Hall 1869:135). In his unpublished ethnography of Rapa, compiled between 1921 and 1922, Stokes (ms) noted that:

Many coconut palms are now scattered through the island. Though vigorous and growing to a fair height, according to report - they drop their fruit before it matures. Other introductions at Tupuaki, on the northern coast, are said to have borne fruit that was 'killed by thunder'.

He also noted that a 'white man who tried to grow coconuts for commerce at the northern end of the harbor apparently abandoned the venture as a failure' (Stokes ms).

Coconut has been introduced within the past 60 years to Rapa, where it is located around Ha'urei village and as isolated trees in some sheltered embayments on the island. On Rapa, these palms currently produce small fruits that do not develop to full maturity, probably as a result of the more sub-tropical climate of the island. On most of the Austral Archipelago, $C$. nucifera fruits do reach full maturity, and the established plantations are used primarily for local consumption and as pig fodder.

Cocos nucifera was probably introduced historically to Pitcairn, where trees produce mature fruits. On Rapanui, however, there has been debate about whether $C$. nucifera was introduced before European contact (Brown 1935). Zizka (1991) suggests the first plants were probably brought to the island in 1877 . There are currently some small plantations and isolated populations of coconut on Rapanui, but few trees produce mature fruits. Coconut trees have also been growing since being planted on Raoul in the 1970s in two coastal locations (Sykes and West 1996). Coconuts regularly wash up on the island shores of the Kermadecs, but none examined have germinated. Sykes and West (1996) suggest coconuts may have washed up after having been dropped off ships in the vicinity of the island.

With the exception of Henderson, C. nucifera has probably been introduced to the subtropical Polynesian islands (Pitcairn, Rapa, Rapanui and Raoul) from cultivated progenitors after European contact, but naturally dispersed populations may have existed before human colonisation. 


\section{Broussonetia papyrifera (L.) Ventenat (Moraceae)}

Matthews (1996) has provided a summary of the biogeography and ethnobotany of Broussonetia papyrifera in Oceania. B. papyrifera is dioecious, having a natural range, with both male and female populations extending from East Asia to mainland Southeast Asia. Limited information is available on its fertile status outside this range, with no flowering specimens known from herbarium records from Remote Oceania. Populations in Remote Oceania may also be derived entirely from clones from an entirely male population. Within Remote Oceania, climate appears not to be a major limiting factor in its distribution, as it is known from early ethnographic and botanical surveys to have been grown in high-latitude situations as far south as the North Island of New Zealand. As yet, no molecular phylogenetic research has been undertaken on $B$. papyrifera populations in Oceania. Matthews (1996) suggests populations of B. papyrifera in Remote Oceania are derived from cultivated progenitors and have been dependent on human dispersal and cultivation for survival.

No archaeobotanical or palaeobotanical material has been identified from Rapa. Orliac (1998) has identified B. papyrifera wood from archaeological charcoal assemblages from Rapanui (dating to 690-500 cal. BP), suggesting the same may be possible from sources on the Austral Archipelago. These trees are small and are unlikely to constitute significant proportions of charcoal unless the oven feature was directly associated with a processing site where heartwood was directly discarded in large quantities. This is likely to be the case at the Akahanga rockshelter site on Rapanui, where B. papyrifera made up 32 percent of the total identified oven charcoal (Orliac 1998:139).

As B. papyrifera does not generally flower or set seed (Whistler 1991:55) within Remote Oceania, it is unlikely pollen or seed will be located in archaeological or sedimentary settings (Matthews 1996). Identifying B. papyrifera pollen is problematic because of the morphological similarity with pollen from other members of the Moraceae and also the Urticaceae family. In the Austral Archipelago, a number of species within the Moraceae are common, including Ficus prolixa var. prolixa and the introduced arboricultural crop, Artocarpus altilis. On Rapa, this problem is conflated by the two species in the indigenous tree genus Streblus ( $S$. anthropophagorum and S. pendulinus). Horrocks et al. (2004a) identified B. papyrifera pollen and hair-type phytoliths from a swamp core from Rangihoua Bay, Northland, New Zealand. Mid-Holocene dates for a section of peat with $B$. papyrifera-type phytoliths, coupled with the likelihood that these plants may not have flowered in Maori cultivations, reduces the validity of this claim.

Stokes (ms) documented bark-cloth production on Rapa, where a 'tapa' beater was located as a surface archaeological find (Kooijman 1972). No first-contact records of bark-cloth production have been noted for any of the islands of the Austral Archipelago, although all of the main ethnographic treatments of the islands suggest its antiquity pre-dates contact.

Ethnographic accounts (e.g. Stokes ms) and botanical records (e.g. Fosberg and St. John 1934) of the Austral Archipelago from as early as the 1920s all indicate B. papyrifera was cultivated within extensive groves, including on Rapa. It is likely that on most Polynesian islands, cultivation became increasingly limited after the introduction of domestic animals, including pigs, cattle and goats. William Colenso (1880:18, in Matthews 1996) suggested the plant was extirpated in New Zealand soon after 1844, due primarily to browsing by cattle. This may well have been the case on the other subtropical Polynesian islands, namely Rapa and Rapanui. Bark-cloth production is now minimal on the islands, with plants generally cultivated within or adjacent to household gardens. Some small groves are still maintained, but only in areas protected from domestic and feral livestock. 


\section{Cordia subcordata Lam. (Boraginaceae)}

Fruit remains of Cordia subcordata from Maha'ulepu cave excavations on Kaua'i Island have been dated to 5945-5300 cal. BP (Burney et al. 2001). Apparently, Sinclair (1885 in Burney et al. 2001) earlier considered C. subcordata to be indigenous to the Hawaiian Islands, but this tree was formerly regarded by many authors as introduced (e.g. Whistler 1991). No macrofossil remains of $C$. subcordata have been located on any of the subtropical Polynesian islands. The tree has been recorded in recent botanical surveys on Henderson, although it is thought to have been introduced. C. subcordata was located in the northern Austral Archipelago, including on Tubuai, during the 1921-1934 surveys, and on Rimatara during the most recent botanical surveys, in the vicinity of local villages.

\section{Probable intentional herbaceous introductions}

There are several herbaceous taxa that may have been intentionally or inadvertently introduced to the Pacific Islands by people. Of the list of herbs probably intentionally introduced into the subtropical Polynesian islands (Table 5), most have been proposed in a number of botanical compendiums by several authors (e.g. Whistler 1991), but none have been recorded in the palaeobotanical record from any of the islands in sediments that exceed the age for human colonisation established by the archaeological record. Many taxa are well known and have been widely discussed in the Polynesian ethnobotanical literature.

Relatively little information is available for many of the herb taxa listed in Table 4. Manihot esculenta Crantz, in the Euphorbiaceae, appears to have been a recent introduction to all of the Austral Islands, where it is now one of the staple foods. Tephrosia pupurea (L.) Pers. appears to have been a recent introduction to the Austral Archipelago, but a pre-contact introduced species to most of Remote Oceania, including the Hawaiian Islands (Whistler 1991). Both species' pollen types are distinctive, but neither have been found in any pollen records from subtropical Polynesian islands.

Three cane-grass species (Erianthus maximus Brongn., Saccharum officinarum L. and Schizostachyum glaucifolium (Rupr.) Munro) are listed by Whistler (1991) as possible pre-contact introductions to most of Remote Oceania. The status of E. maximums and S. glaucifolium is unclear for the Austral Archipelago, as they have only been recorded since 1934 and have been rarely noted in the most recent botanical surveys. Sugarcane (Saccharum officinarum) was noted by Stutchbury (Branagan 1996) on Rurutu in 1826 and by Cuming (St. John 1940) on Rapa in 1832 , but these records are not early enough to determine its pre-contact introduction. $S$. officinarum is still cultivated on most of the Austral Islands, with some formerly large stands either poorly maintained or abandoned. Sugarcane phytoliths have been identified on some archaeological sites in the Pacific, but none have been located in the few samples examined for phytoliths from sites on Rapa.

Arrowroot (Tacca leontopetaloides (L.) Kuntze) was identified by both Stutchbury (Branagan 1996) and Paulding (1970) on Tubuai in 1826. These late-first-contact records are not early enough to determine whether or not it was grown before European contact. Cranwell (1964) identified Taccaceae-type pollen from the Arahu lignite deposit on Rapa, but this is unlikely to represent this species. The plant is now rarely grown on the Austral Archipelago.

Two ginger species, the tumeric Curcuma longa (L.) and Zingiber zerumbet (L.) Smith, are also listed in Table 4. C. longa was recorded on Rapa during St. John and Fosberg's 1934 botanical survey, but has not been recorded in recent surveys. The ginger $Z$. zerumbet was only recorded in the Austral Archipelago, including Rapa, by 1934, and has become naturalised on most of the islands. 


\section{Inadvertent herbaceous introductions (weeds)}

The problem of characterising the phytogeography of weeds in the Pacific was illustrated by Guppy (1906:416) in his analysis of the long-distance dispersal mechanisms of Pacific plants:

Weeds follow the cultivators in all climates ... [and the cultivator's] share in weed dispersal is often as not merely restricted to producing the conditions favourable to the growth of weeds, and that the seeds are often brought by birds and other agencies.

Guppy lists Waltheria americana (syn. W. indica), Oxalis corniculata (Oxalidaceae), Urena lobata (Malvaceae), Sida spp. (Malvaceae) and Bidens pilosa (Asteraceae) among a list of 37 possible 'aboriginal weeds' that may have reached the islands through a range of dispersal mechanisms, including purposeful transport by people (Guppy 1906:604-605). He defines aboriginal weeds on the basis of vagility, as well as historically documented locations cited by James Cook's botanists during the 1769-1779 voyages to the Pacific. The involvement of humans in weed dispersal, as Guppy admits, is complicated not only by the range of other possible dispersal mechanisms, but also by the plants' uncertain geographical origins, given their capacity to naturalise in many different habitats. Contrary to Guppy, Ridley (1930:634) to some extent downplays the role of alternative dispersal mechanisms, suggesting some of these plants (e.g. Oxalis corniculata) were more likely to be inadvertent introductions brought directly by people. The status of weeds as aboriginal introductions to islands in Remote Oceania has been addressed specifically by Whistler (1988) and Leach (2005), and is referred to in the most recent compendiums of island floras (e.g. Wagner et al. 1990; Webb et al. 1998; Florence 1997, 2004).

Table 5 lists a number of weed species that may have been inadvertently introduced to the subtropical Polynesian islands before European contact. Determinations of pre-contact presence are based primarily on the records of the botanists on Cook's voyages to other islands in Remote Oceania (e.g. Forster 1786; Nelson in St. John 1978; Drake de Castillo 1893; Merrill 1954; Solander in Leach 2005), but also on relevant palynological records from these same islands. For the Austral Archipelago, determinations of the pre-contact presence of a number of weed species have been inferred by Florence $(1997,2004)$ in the latest compendium of the Flore de la Polynésie française, following Drake de Castillo (1893) and Brown (1935). First-contact accounts are concentrated on economic species (e.g. Colocasia esculenta), and no records of weed species, apart from cultivated vegetables, were recorded between 1606 and any of the earliest botanical compendiums for the subtropical Polynesian islands.

The palaeobotanical record for the Amaranthaceae, Malvaceae, Poaceae, Polygonaceae and Solanaceae, in which several inadvertent weed species (Table 5) are represented, is complicated by the presence of indigenous representatives of these families on the islands. The pollen morphology of these families is often indistinguishable to genus or species, and thus the presence of pollen cannot be used to determine the presence of these weed species.

\section{Ludwigia octovalvis (Kunth) Raven (Onagraceae): syn. Jussiaea villosa, J. suffruticosa}

Ludwigia octovalvis appears to have originated as a pan-tropical species like most of its close relatives (e.g. L. peoploides), but its current distribution extends also into sub-tropical and temperate areas, where it is commonly found invading wetland environments. L. octovalvis is noted as a persistent weed in irrigated Colocasia esculenta pondfields throughout the Pacific, where in abandoned fields it can form dense monotypic stands. Kirch (1994) noted that L. octovalvis is a common weed on field systems in the western Pacific island of Futuna. Riley (1926) first collected this plant from Rapa in 1924, the earliest known record for the Austral Archipelago. 
Fosberg and St. John (1934) later recorded L. octovalvis from most of the Austral Islands.

Guppy (1906:533) has indicated that the seeds of Ludwigia (Jussiaea) demonstrate a degree of buoyancy ('a few days'), and may be capable of long-distance dispersal, although this has not been successfully demonstrated. It seems more likely that this plant was transported as an inadvertent introduction embedded in soil attached to plants traded between or introduced to islands.

L. octovalvis pollen has been recorded in the upper human-impact horizons of palynological records from the Hawaiian Islands (e.g. Athens and Ward 1991, 1997) but also Yap in Micronesia (Dodson and Intoh 1999) and in post-European contact-period sediments on Moorea in French Polynesia (Parkes and Flenley 1997; Parkes 1997). Athens (1997:269) maintains that Ludwigia pollen can be constrained to Polynesian-phase levels as early as about A.D. 1250. Athens and Ward (1997) located Ludwigia pollen from two samples associated with Colocasia esculenta, Aleurites moluccana and Cordyline fruticosa pollen from a sedimentary core from the Maunawili Valley, O'ahu, of an age younger than $655 \mathrm{cal}$. BP.

The Hawaiian records contrast with the Austral Archipelago pollen record in which $L$. octovalvis appears late in the human-impact horizons from both Rapa and Rimatara. Ludwigia pollen, as on the Hawaiian Islands, is likely to represent a population of weeds growing on or adjacent to active or fallow Colocasia pondfield cultivations, but the lack of pollen from these weeds in the early agricultural horizons, defined by the presence of Colocasia pollen, attests to its late introduction.

The lateness of the Ludwigia record in the Austral Archipelago and Mo'orea may be explained by two historical factors. The increased trade of produce between more distant archipelagos during the early-European-contact period (e.g. as recorded for Alocasia from the Cook Islands) might explain the late arrival $L$. octovalvis and other agricultural weeds. Alternatively, if $L$. octovalvis was present on the island during the early Polynesian-colonisation period, it is possible agriculturalists prevented the weed from establishing. During the European-colonisation period, the wide-scale abandonment of agricultural systems that followed population decline may have allowed already present $L$. octovalvis to encroach into fallow or abandoned fields.

Despite the historical and palaeobotanical indications, it is still plausible that L. octovalvis is indigenous to islands northwest of Rapa, but not to any of the subtropical Polynesian islands.

\section{Commelina diffusa Burm.f. (Commelinaceae): syn. C. nudiflora, C. pacifica}

Commelina diffusa is regarded as a pan-tropical species, but its precise origin is unclear. On Cook's second voyage to the Pacific in 1773, Georg Forster collected C. pacifica (syn. C. diffusa) from Tonga (Forster 1786:358) and New Caledonia. The plant was also known from the Hawaiian Islands at the time of Cook's arrival (Hillebrand 1888).

Like L. octovalvis, C. diffusa is noted as a persistent weed in irrigated Colocasia esculenta pondfields throughout the Pacific, where in abandoned fields it can form dense monotypic stands. According to Meyer (2004) and Florence (1997), this plant is regarded as an invasive weed, where on Mangareva (Gambier Islands, French Polynesia) it threatens a small population of the rare endemic plant Pilea sancti-johannis (Urticaceae), along with a number of other indigenous species. Located on Rapa in the earliest botanical surveys and on Pitcarin and Rapanui in recent surveys, it appears to be equally invasive, especially in lowland swamp and marsh environments and abandoned Colocasia agricultural fields.

C. diffusa pollen has also been recorded in the upper human-impact horizons of palynological records from the Hawaiian Islands (e.g. Beggerley 1990; Athens and Ward 1997) and in probable 
post-European-contact sediments on Mo'orea (Parkes and Flenley 1990; Parkes 1997), but less so from other sites in the Pacific. Like L. octovalvis, C. diffusa appears to be a pre-Europeancontact introduction to the Hawaiian Islands. Again, the Hawaiian records contrast with Austral Archipelago pollen records in which $C$. diffusa appears late in the human-impact horizons from both Rapa and Rimatara (Prebble et al. submitted; Prebble and Wilmshurst In press).

\section{Sonchus oleraceus L. (Asteraceae)}

Leach (2005:278) suggests edible foliage of Sonchus (specifically referring to S. aspera) may have been an intentional introduction into the Pacific, distributed as far south as New Zealand. She also suggests its ecological preference for disturbed soils 'would also have given its seeds a good chance of accidental inclusion with dirt-encrusted root crops'. Solander, on James Cook's first voyage to New Zealand in 1769, identified Sonchus oleraceus (possibly S. aspera) from a range of cultivation sites (Solander in Leach 2005). On Cook's second voyage in 1773-1774, Georg Forster collected S. oleraceus from Tonga (Forster 1786) and from Norfolk Island (Hoare 1988; Hicks 1988), although some of these determinations are debatable (Leach 2005).

Cheeseman (1903), in compiling his early flora of Rarotonga, suggested the plant is indigenous to the Pacific region. Such an interpretation may have come in recognition of its very widespread representation across most islands in the Pacific. Fosberg and St. John (1934) recorded S. oleraceus from Rapa and the other populated Austral Islands in 1934.

Palynological records of S. oleraceus have not been forthcoming from Remote Oceania. Trace counts of $S$. oleraceus pollen were identified in four records from Rapa (Prebble et al. submitted). The majority of these records suggest this plant was introduced post-European contact, as it is most frequently in strata associated with Commelina diffusa and Ludwigia octovalvis in the uppermost human-impact sequences.

\section{Canna indica L. (Cannaceae)}

The origin of this pan-tropical plant is uncertain, as it is naturalised throughout its range. Also uncertain is the timing of its introduction or naturalisation in Remote Oceania. The earliest botanical record of the presence of $C$. indica in the subtropical Polynesian islands comes from Fosberg and St. John's 1934 survey of Rapa. The pollen record from Rapa suggests the arrival of C. indica was late, and perhaps after European contact (Prebble et al. submitted), as was the case on Raoul (Sykes and West 1996).

\section{Cyclosorus interruptus (Willd.) H. Ito (Thelypteridaceae)}

Along with Ludwigia octovalvis, Nelson also collected Cyclosorus interruptus from the Hawaiian Islands in 1779 (St. John 1978). Leach (2005) suggests that despite not being recorded by Daniel Solander in New Zealand, its presence in far-northern New Zealand suggests an inadvertent relationship with Colocasia introduction and production, given this was the prime area for introduction of a tropical cultigen (Matthews 1985). Leach (2005 after Sykes) suggests that for most of the Cook Islands, this fern is dominant only in areas around Colocasia fields. For this reason, Leach suggests Cyclosorus interruptus may be one of many good candidates for Polynesian introduction to New Zealand.

Cyclosorus interruptus was not identified in any of the palynological records obtained from Rapa, but on Rimatara, two records from the Maunutu moat swamp provide good evidence that this shield fern may have been introduced to the island before European contact. In both cores, Cyclosorus interruptus was present in the earliest anthropogenic sediments, in some cases in high proportions (Prebble and Wilmshurst In press). 
Table 6. Known and probable Polynesian plant introductions to the subtropical Polynesian islands and northern New Zealand.

\begin{tabular}{|c|c|c|c|}
\hline Island & Inadvertent introductions & Intentional introductions & References \\
\hline Raivavae & $\begin{array}{l}\text { Achyranthes aspera var. aspera, } \\
\text { Bidens pilosa, Sigesbeckia orientalis, } \\
\text { Solanum americanum }\end{array}$ & $\begin{array}{l}\text { Aleurites moluccana, Cocos nucifera, Broussonetia } \\
\text { papyrifera, Colocasia esculenta, Cordyline fruticosa, } \\
\text { Ipomoea batatas, Lagenaria siceraria, Musa sp., } \\
\text { Thespesia populnea }\end{array}$ & Meyer (unpublished) \\
\hline Henderson & Solanum americanum & $\begin{array}{l}\text { Aleurites moluccana, Colocasia esculenta, } \\
\text { Cordyline fruticosa,Cyrtosperma merkusii, Musa sp., } \\
\text { Thespesia populnea }\end{array}$ & Florence et al. (1995) \\
\hline Pitcairn & $\begin{array}{l}\text { Achyranthes aspera var. aspera, } \\
\text { Bidens pilosa }\end{array}$ & $\begin{array}{l}\text { Aleurites moluccana, Cocos nucifera, Colocasia esculenta, } \\
\text { Cordyline fruticosa, Thespesia populnea }\end{array}$ & Florence et al. (1995) \\
\hline Rapanui & Rorippa sarmentosa & $\begin{array}{l}\text { Broussonetia papyrifera, Colocasia esculenta, } \\
\text { Cordyline fruticosa,Ipomoea batatas }\end{array}$ & Zizka (1991) \\
\hline Rapa & $\begin{array}{l}\text { Achyranthes aspera var. aspera, } \\
\text { Bidens pilosa, Sigesbeckia orientalis, } \\
\text { Solanum americanum }\end{array}$ & $\begin{array}{l}\text { Aleurites moluccana, Hibiscus tiliaceus, Broussonetia } \\
\text { papyrifera, Colocasia esculenta, Cordyline fruticosa, } \\
\text { Ipomoea batatas, Lagenaria siceraria, Musa sp., } \\
\text { Thespesia populnea }\end{array}$ & Meyer et al. (2004) \\
\hline Norfolk & $\begin{array}{l}\text { Achyranthes aspera var. aspera, } \\
\text { Bidens pilosa, Sigesbeckia orientalis, } \\
\text { Solanum americanum }\end{array}$ & Cordyline fruticosa, Musa sp. & Green (1994) \\
\hline Raoul & $\begin{array}{l}\text { Achyranthes aspera var. aspera, } \\
\text { Bidens pilosa, Sigesbeckia orientalis, } \\
\text { Solanum americanum }\end{array}$ & Aleurites moluccana, Cordyline fruticosa & Sykes (1977) \\
\hline $\begin{array}{l}\text { Subtropical } \\
\text { northern } \\
\text { New Zealand }\end{array}$ & $\begin{array}{l}\text { Bidens pilosa, Sigesbeckia orientalis, } \\
\text { Solanum americanum }\end{array}$ & $\begin{array}{l}\text { Broussonetia papyrifera, Colocasia esculenta, } \\
\text { Cordyline fruticosa, Ipomoea batatas, } \\
\text { Lagenaria siceraria }\end{array}$ & $\begin{array}{l}\text { Best (1925); Leach (1984); } \\
\text { Webb et al. (1988) }\end{array}$ \\
\hline
\end{tabular}

Table 7. Possible Polynesian plant introductions to the subtropical northern New Zealand.

\begin{tabular}{ll}
\hline Inadvertent introductions & Justification \\
\hline Achyranthes aspera var. aspera & Naturalised on all of the subtropical Polynesian islands including northern New Zealand. \\
Eleusine indica & Naturalised on all of the subtropical Polynesian islands except Henderson. \\
\hline Intentional introductions & Justification \\
\hline Aleurites moluccana & Grows successfully without cultivation on Raoul. An important fuel source for torches/candles. \\
Cocos nucifera & Poor fruiting populations have been established on all of the subtropical Polynesian islands, some from \\
Hibiscus tiliaceus & beach drift propagules. Plants may have been planted then trees subsequently died. \\
Musa sp (AAB group syn. M. x paradaisica, & Gaturalised on Raoul, a common strand taxa across much of Remote Oceania and likely to have been \\
M. Sapientum; Musaceae: section Eumusa) & introduced on many islands. An important substitute fibre plant. \\
Thespesia populnea & A common strand taxa across much of Remote Oceania. Grows successfully in cultivation on Rapa and \\
& Rapanui. An important substitute fibre plant. \\
\hline
\end{tabular}




\section{Polynesian introductions to subtropical New Zealand}

In Table 6, a summary list of probable candidates for plant introduction to the subtropical islands and northern subtropical New Zealand is provided. Given the general geographical limitations posed to successful establishment of tropical and subtropical plant taxa in subtropical New Zealand, I also present a list of justifications for regarding these taxa as Polynesian introductions (Table 7). Of the inadvertent weed introductions, plants with hooked seeds, namely Bidens pilosa, are represented on most islands. The distribution of Bidens pilosa, however, is complicated by alternative long-distance dispersal by birds. Other species such as Achyranthes aspera and a number of grasses may also have been dispersed by migratory birds, lodged in soil or trapped in feathers. The patchy distribution of some of the non-hooked seed species across the subtropical islands suggests some limitation on long-distance dispersal.

Of the intentional introductions presented in Table 6, Cordyline fruitcosa is represented on all islands, including northern New Zealand. Cordyline can reproduce vegetatively, and produces abundant seeds readily dispersed by birds, thus naturalising on most subtropical environments. Other taxa, particularly the staple food plants, have not survived on the abandoned subtropical islands. This strongly implies that agricultural maintenance was required for the ongoing survival of these taxa. Other cultural factors may explain the decline or survival of these taxa, but these are not discussed here.

\section{Conclusions}

I have presented a partial analysis of known, probable and potential candidates for humanmediated introduction to the subtropical Polynesian islands of Remote Oceania. The distribution of these plants is difficult to compare, given the lack of archaeobotanical data for the abandoned islands and the bias towards those islands occupied at European contact. But some broad conclusions can be drawn. As Anderson (2001) suggests, the subtropical islands of Remote Oceania were difficult to colonise prehistorically, given they were relatively resource poor - too warm to support the rich coastal biomass of mammals, birds and fish which characterise more temperate islands. He also suggests the subtropics can generally be viewed as being too cool for the translocation of tropical agricultural production, which meant that for many islands, long-term survivability of colonising populations depended on subtle differences between islands. Despite these differences, Anderson (2001:21) suggests settlement on the abandoned subtropical Polynesian islands may not have been due to the lack of agricultural potential. Indeed, agricultural production on Norfolk and Pitcairn appears not to be constrained by lack of suitable soil and rainfall.

Regarding the subject of taxa introduced to subtropical New Zealand by Polynesians, the diversity and abundance of faunal resources may have meant that the diversity of agricultural crops seen in the tropical Pacific became redundant in sustaining long-term settlement. Nevertheless, the ephemeral occupation records for Norfolk (Anderson et al. 2001; MacPhail et al. 2001), Henderson and Pitcairn (Weisler 1997; Horrocks and Weisler 2006) present a diverse array of plant introductions, and on that basis, I suggest a similar situation may have existed on New Zealand. The size and temperate climate of New Zealand limits the preservation of botanical remains of tropical/subtropical plants, already limited by generally lower temperatures and frosts.

Finally, there are two problems in assessing the botanical status of plants that have a distribution or historical presence that may have been influenced by people. Firstly, assessing the status of introduced taxa that may have become naturalised on islands once released is 
complex, and may be represented in the different lines of botanical evidence in different ways. Secondly, the status of some taxa that may have become naturalised or declined on their own accord, particularly in response to other environmental factors independent of human activity, is equally difficult to assess. The following would enable a better understanding of Polynesian plant introductions in Remote Oceania:

- Development of phylogeographic data based on fine-resolution molecular phylogenies.

- Greater emphasis on the taxonomic resolution of the palaeobotanical and archaeological record, focusing on key taxa with well-defined phytogeographic distributions.

- Spatial sampling approaches to anthropogenic palaeoenvironmental sequences at a greater number of sites and on more islands.

\section{Acknowledgments}

In 2001, Atholl Anderson published a paper titled 'No Meat on that Beautiful Shore' in the International Journal of Osteoarchaeology. In the paper, he explored the role of impoverished faunas of the subtropical Polynesian islands, in the context of the prehistoric abandonment of the 'Mystery islands'. Drawing on the same title, this contribution was put together on Atholl's insistence that we need to know more about Polynesian weeds and introduced floras. I thank Jean-Yves Meyer for botanical data pertaining to the Austral Archipelago. I also thank Jean Kennedy and Geoff Hope (both of the ANU) for comments on earlier editions of this paper.

\section{References}

Anderson, A. 1980. The archaeology of Raoul Island (Kermadecs) and its place in the settlement history of Polynesia. Archaeology and Physical Anthropology in Oceania 15:131-141.

Anderson, A. 1996. Discovery of a prehistoric habitation site on Norfolk Island. Journal of the Polynesian Society 105:479-486.

Anderson, A. 2001. No meat on that beautiful shore: The prehistoric abandonment of subtropical Polynesian islands. International Journal of Osteoarchaeology 11:14-23.

Anderson, A., I. Smith and P. White 2001. Archaeological fieldwork on Norfolk Island. In A. Anderson and P. White (eds), The prehistoric archaeology of Norfolk Island, southwest Pacific, pp. 11-32. Sydney: Records of the Australian Museum Supplement.

Athens, J.S. and J.V. Ward 1996. A sediment coring record at Kapunahala Marsh, Kane'ohe, O'ahu, Hawaii. Honolulu: International Archaeological Research Institute.

Athens, J.S. and J.V. Ward 1997. The Maunawili core: Prehistoric inland expansion of settlement and agriculture, O'ahu, Hawai' i. Hawaiian Archaeology 6:37-51.

Athens, J.S., J.V. Ward and H.D. Tuggle 1997. Environment, vegetation change, and early human settlement on the 'Ewa Plain: Paleoenvironmental investigations. Honolulu: International Archaeological Research Institute.

Barrau, J. 1965. Histoire et prehistoire horticoles de l'Oceanie tropical. Journal de la Société des Océanistes 21:55-78.

Best, E. 1925. Maori agriculture. New Zealand, Board of Maori Ethnological Research for the Dominion Museum, Wellington. 
Branagan, D.F. 1996. Science in a sea of commerce: Seas trading adventure (1825-1827), by Samuel Stutchbury. Rosebery: Hippo Books.

Brown, F.B.H. 1931. Flora of Southeastern Polynesia I. Monocotyledons. Bishop P. Bishop Museum Bulletin 84.

Brown, F.B.H. 1935. Flora of Southeastern Polynesia III. Dicotyledons. Bishop P. Bishop Museum Bulletin 130.

Burtenshaw, M.K. 1999. Maori gourds: An American connection? Journal of the Polynesian Society 108:427-433.

Carlquist, S. 1996. Plant dispersal and the origin of the Pacific island floras. In A. Keast and S.E. Miller (eds), The origin and evolution of Pacific Island biotas, New Guinea to Eastern Polynesia: Patterns and processes, pp. 153-164. Amsterdam: SPB Academic Publishing.

Cheeseman, T.F. 1888. On the flora of the Kermadec Islands; with notes on the fauna, Transactions and Proceedings of the New Zealand Institute 20:151-181.

Clark, J.T. and A.O. Cole 1997. Environmental change and human prehistory in the central Pacific: Archaeological and palynological investigations on Totoya Island. Suva: The Fiji Museum.

Clarke, A.C., M.K. Burtenshaw, P.A. Mclenachan, D.L. Erickson and D. Penny 2006. Reconstructing the origins and dispersal of the Polynesian bottle gourd (Lagenaria siceraria). Molecular Biology and Evolution 23:893-900.

Close, R.C., N.T. Moar, A.I. Tomlinson and A.D. Lowe 1978. Aerial dispersal of biological material from Australia to New Zealand. International Journal of Biometeorology 22:1-9.

Colenso, W. 1880. On the vegetable food of the ancient New Zealanders before Cook's visit. Transactions of the New Zealand Institute 13:3-38.

Corney, B.G. 1913-1919. The quest and occupation of Tahiti by emissaries of Spain 32. London: Hakluyt Society.

Cranwell, L.M. 1964. Rapa Island coal and its microfossils: A preliminary report. In L.M. Cranwell (ed), Ancient Pacific Floras, pp. 43-47. Honolulu: University of Hawaii Press.

Davies, J. 1851. A Tahitian and English dictionary. London: London Missionary Society Press.

Decker-Walters, D., J. Staub, A. Lopez-Sese and E. Nakata 2001. Diversity in landraces and cultivars of bottle gourd (Lagenaria siceraria; Cucurbitaceae) as assessed by random amplified polymorphic DNA. Genetic Resources and Crop Evolution 48:369-380.

Denham, T., F.J. Eble, B. Winsborough and J.V. Ward 1999. Palaeoenvironmental and Archaeological Investigations at 'Ohi'apilo Pond, Leeward Coast of Moloka'i, Hawai' i. Hawaiian Archaeology 7:35-59.

Drake De Castillo, E. 1893. Flore de la Polynésie française. Paris: G. Masson.

Ellison, J. 1994. Palaeo-lake and swamp stratigraphic records of Holocene vegetation and sea-level changes, Mangaia, Cook Islands. Pacific Science 48:1-15.

Endlicher, S.F.L. 1833. Prodromus Florae Norfolkicae. Vienna: F. Beck.

Flenley, J.R. S.M. King, J. Jackson and C. Chew 1991. The Late Quaternary vegetational and climatic history of Easter Island. Journal of Quaternary Science 6:85-115.

Florence, J. 1997. Flore de la Polynésie française. Collection Faune et Flore tropicales, vol 1. Paris: Éditions de l'Orstom.

Florence, J. 2004. Flore de la Polynésie française. Collection Faune et Flore tropicales, vol. 2. Paris: Éditions de IRD, Publications Scientifiques, Museum National D'Histoire Naturelle.

Florence, J., S. Waldren and A.J Chepstow-Lusty 1995. The flora of the Pitcairn Islands: A review. Biological Journal of the Linnean Society 56:79-119.

Fosberg, F.R. 1960. A theory on the origin of the coconut. In Symposium on the impact of man on humid tropics vegetation, pp. 73-75. Goroka, Territory of Papua and New Guinea. Canberra: Commonwealth Government Printers. 
Fosberg, F.R., M.H. Sachet and D.R. Stoddart 1983. Henderson Island (South eastern Polynesia): summary of current knowledge Atoll Research Bulletin 272:1-47.

Fosberg, F.R. and H. St. John 1934. Check list and field notebook of the plants of Southeastern Polynesia: Society Islands, Tuamotus, Austral Islands, Rapa. Honolulu, B.P. Bishop Museum Herbarium Archive.

Green, P.S. 1994. Flora of Australia Volume 49, Oceanic Islands 1, Canberra: Government Publishing Service.

Green, R.C. 2005. Sweet potato transfers in Polynesian prehistory In C. Ballard, P Brown, R.M. Bourke and T. Harwood (eds), The sweet potato in Oceania: A reappraisal, pp. 43-62. Canberra: Oceania Monograph.

Guppy, H.B. 1906. Observations of a naturalist in the Pacific between 1896 and 1899. London: Macmillan.

Hall, J.V. 1869. On the island of Rapa. Transactions and Proceedings of the New Zealand Institute $1: 128-134$.

Harries, H., L. Baudouin and R. Cardeña 2004. Floating, boating and introgression: Molecular techniques and the ancestry of the Coconut palm populations on Pacific Islands, Ethnobotany Research and Applications 2:37-53.

Harries, H.C. 1990. Malesian origin for a domestic Cocos nucifera. In P. Baas, K. Kalkman and R. Geesink (eds), The plant diversity of Malesia Proceedings of the Flora Malesiana Symposium commemorating Prof CGGJ van Steenis. Kluwer, pp. 351-357. Dordrecht: Academic Publishers.

Hather, J. and M.I. Weisler 2000. Prehistoric giant swamp taro (Cyrtosperma chamissonis) from Henderson Island, Southeast Polynesia. Pacific Science 54:149-156.

Hather, J.G. 1994. The identification of charred root and tuber crops from archaeological sites in the Pacific. In J.G. Hather (ed), Tropical archaeobotany: Applications and new developments, pp. 51-64. London: Routledge.

Heiser, C.B.J. 1973. Variation in the bottle gourd. In B. Meggers, E. Ayensu, and W. Duckworth (eds), Tropical forest ecosystems in Africa and South America: A comparative review, pp. 121-128. Washington: Smithsonian Institution Press.

Heiser, C.B.J. 1979. The gourd book. University of Oklahoma: Oklahoma.

Henry, T. 1928. Ancient Tahiti. Bernice P. Bishop Museum Bulletin 48.

Heyerdahl, T. 1952. American Indians in the Pacific. London: Allen and Unwin.

Heyerdahl, T. 1963. Prehistoric voyages as agencies for Melanesian and South American plant and animal dispersal to Polynesia. In J. Barrau (ed), Plants and the migrations of the Pacific peoples, pp. 23-35. Honolulu: Bishop Museum Press.

Heyerdahl, T. and E.N. Ferdon (eds) 1961. Reports of the Norwegian Archaeological Expedition to Easter Island and the East Pacific, 1955-1956. Monographs of the School of American Research and the Kon Tiki Museum 1(24). London: Allen and Unwin.

Higham, T.F.G., A. Anderson and C. Jacomb 1999. Dating the first New Zealanders: The chronology of Wairau Bar. Antiquity 73:420-427.

Higham, T.F.G. and L. Johnson 1996. The prehistoric chronology of Raoul Island, the Kermadec. Group Archaeology in Oceania 31:207-213.

Hinkle, A. 2004. The distribution of a male sterile form of Ti (Cordyline fruticosa) in Polynesia: A case of human selection? Journal of the Polynesian Society 113:263-290.

Hoare, M. 1987. Norfolk Island: An outline of its history 1774-1987. Brisbane: University of Queensland Press.

Hogg, A.G. T.F.G. Higham, D.J. Lowe, J.G. Palmer, P.J. Reimer and R.M. Newnham 2003. A wigglematch date for Polynesian settlement of New Zealand. Antiquity 77:116-125.

Hooker, J.D. 1856. On the botany of Raoul Island, one of the Kermadec Group in the South Pacific Ocean, Proceedings of the Linnean Society of London 1:125-129.

Horrocks, M., P.A. Shane, I.G. Barber, D.M. D'costa and S.L. Nichol 2004a. Microbotanical remains 
reveal Polynesian agriculture and mixed cropping in early New Zealand. Review of Palaeobotany and Palynology 131:147-157.

Horrocks, M. and L. Lawlor 2006. Plant microfossil analysis of soils from Polynesian stonefields in South Auckland, New Zealand. Journal of Archaeological Science 33:200-217.

Horrocks, M. and M.I. Weisler 2006. Analysis of plant microfossils in archaeological deposits from two-remote archipelagos: The Marshall Islands, Eastern Micronesia, and the Pitcairn Group, Southeast Polynesia. Pacific Science 60:261-280.

Hotta, M. 2002. The Origins and Spread of Tuber Crops (Imo). In S. Yoshida, and P.J. Matthews (eds), Vegeculture in Eastern Asia and Oceania. Japan Center for Area Studies, pp.17-30. Osaka: National Museum for Ethnology.

Hunt, T.L. and C.P. Lipo 2006. Late colonization of Easter Island. Science 311:1603-1606.

Johnson, L. 1995. In the midst of a prodigious ocean. Auckland Conservancy Historic Resources Series 11.

Kennett, D., A. Anderson, M. Prebble, E. Conte and J. Southon 2006. Prehistoric human impacts on Rapa, French Polynesia. Antiquity 80:340-354.

Kirch, P.V. 1994. The wet and the dry: Irrigation and agricultural intensification in Polynesia. Chicago: University of Chicago Press.

Kirch, P.V., J.R. Flenley, D.W. Steadman, F. Lamont and S. Dawson 1992. Ancient environmental degradation: Prehistoric human impacts to an island ecosystem: Mangaia, Central Polynesia. National Geographic Research and Exploration 8:166-179.

Kirch, P.V. and D.E. Yen 1982. Tikopia: The prehistory and ecology of a Polynesian outlier. Honolulu: Bishop Museum Press.

Kooijman, S. 1972. Tapa in Polynesia. Bernice P. Bishop Museum Bulletin No. 234. Honolulu: Bishop Museum Press.

Leach, H. 1984. 1,000 years of gardening in New Zealand. Wellington: A. H. and A. W. Reed.

Leach, H. 2005. Gardens without weeds? Pre-European Maori gardens and inadvertent introductions. New Zealand Journal of Botany 43:271-284.

Lebot, V. 1999. Biomolecular evidence for plant domestication in Sahul. Genetic Resources and Crop Evolution 46:619-628.

Lebrun, P., L. Grivet and L. Baudouin 1999. Use of RFLP markers to study the diversity of the coconut palm. In C. Oropeza, J.L. Verdeil, G.R. Ashburner, R. Cardeña, R. and J.M. Santamarja (eds), Current advances in coconut biotechnology, pp. 73-87. Dordrecht: Kluwer Academic Publishers.

Macphail, M.K., G.S. Hope and A. Anderson 2001. Polynesian plant introductions in the Southwest Pacific: Initial pollen evidence from Norfolk Island In A. Anderson and P. White (eds), The prehistoric archaeology of Norfolk Island, southwest Pacific, pp.123-134. Sydney, Records of the Australian Museum Supplement,

Matthews, P.J. 1985. Nga taro o Aotearoa, Journal of the Polynesian Society 94:253-272.

Matthews, P.J. 1996. Ethnobotany, and origins of Broussonetia papyrifera in Polynesia: An essay on tapa prehistory In J.M. Davidson, G. Irwin, B.F. Leach, A. Pawley, and D. Brown (eds), Oceanic culture history: Essays in honour of Roger Green. Auckland: New Zealand Journal of Archaeology Special Publication.

Matthews, P.J. 2004. Genetic diversity in Taro, and the preservation of culinary knowledge. Ethnobotany Research and Applications 2:57-71.

Merrill, E.D. 1946. Man's influence on the vegetation of Polynesia, with special reference to introduced species, Chronica Botanica 10:334-345.

Merrill, E.D. 1954. The botany of Cook's voyages, Chronica Botanica 14:164-383.

Meyer, J.-Y. 2004. Threat of invasive alien plants to native flora and forest vegetation of Eastern Polynesia. Pacific Science 58:357-375.

Morrison, J. 1935. The journal of James Morrison, boatswain's mate of the Bounty describing the mutiny and subsequent misfortunes of the mutineers together with an account of the island of Tahiti, with an introduction by O.Rutter. London: Golden Cockerel Press. 
Mueller-Dombois, D. and F.R. Fosberg, 1998. Vegetation of the tropical Pacific islands. New York: Springer.

Oliver, W.R.B. 1910. The vegetation of the Kermadec Islands. Transactions and Proceedings of the New Zealand Institute 42:118-175.

Orliac, C. 1998. Données nouvelles sur la composition de la flore de l'île de Pâques, Journal de la Société des Océanistes 107:135-143.

Parkes, A. 1997. Environmental change and the impact of Polynesian colonization: Sedimentary records from Central Polynesia In P.V. Kirch and T.L. Hunt (eds), Historical ecology in the Pacific Islands, pp. 166-199. New Haven: Yale University Press.

Parkinson, S. 1973. A journal of a voyage to the South Seas in his Majesty's ship, the Endeavour, Adelaide: Library Board of South Australia.

Paulay, G. and T. Spencer 1989. Vegetation of Henderson Island. Atoll Research Bulletin 328.

Paulding, H. 1970. Journal of a cruise of the U.S. Schooner Dolphin. Honolulu: University of Hawaii Press.

Prebble, M. 2006. Islands, floras and history: An environmental history of plant introduction and extinction on the Austral Islands, French Polynesia. Unpublished PhD thesis, Australian National University, Canberra.

Prebble, M. and A. Anderson In press. The archaeobotanical record from rockshelter deposits from Rapa. In A. Anderson and D. Kennett (eds), The prehistory of Rapa: An isolated high island in French Polynesia. New Zealand Archaeological Association Monographs.

Prebble, M., D. Kennett, J. Southon, N. Porch and A. Anderson Submitted. Tracing human impact on islands in Remote Oceania: Holocene coastal swamp forest profiles from Rapa, Austral Islands, French Polynesia. Quaternary Science Reviews.

Prebble, M. and J. Wilmshurst In press. Palaeoecological detection of initial human impacts on island environments in Remote Oceania using introduced plant cultigen pollen and rat-gnawed seeds. Biological Invasions.

Pritchard, W.T. and J.F. Simpson 1830. Extracts from the journal of Messrs. Pritchard and Simpson, during their voyage to the islands of Tubuai, Raivavai, Rapa. London: Missionary Society Transactions.

Ridley, H.N. 1930. The dispersal of plants throughout the world. London: Lovell Reeve and Co.

Robinson, W.A. 1957. To the great southern sea. London: Book Club Associates.

Rosendahl, P.H. and D.E. Yen 1971. Fossil sweet potato remains from Hawaii, Journal of the Polynesian Society 80:379-385.

Sauer, J.D. 1971. A re-evaluation of the coconut as an indicator of human dispersal In C.L. Riley, C.W. Kelley, C.W. Pennington and R.L. Rands (eds), Man across the sea, pp. 309-319. Austin: University of Texas.

Seemann, B. 1865-73. Flora Vitiensis: A description of the plants of the Viti or Fiji Islands with an account of their histories, uses, and properties. London, L. Reeve and Company.

Shineberg, D.E. 1986. Archibald Menzies account of the visit of the Discovery to Rapa and Tahiti, 22 December 1791-25 January 1792. Pacific Studies 9:59-102.

Skottsberg, C. 1956 The natural history of Juan Fernandez and Easter Island. Uppsala: Almqvist and Wiksells.

Smith, A.C. 1981. Flora Vitiensis Nova, vol. 1. Hawaii: Pacific Tropical Botanic Garden.

Spriggs, M. 1984. Early coconut remains from the South Pacific. Journal of the Polynesian Society 93:71-76.

St. John, H. 1940. Itinerary of Hugh Cuming in Polynesia. B.P. Bishop Museum Occasional Paper 16:81-90.

St. John, H. 1976. Revision of the Genus Pandanus Stickman. Part 40. The Fijian species of the section Pandanus. Pacific Science 30:249-315. 
St. John, H. 1978 The first collection of Hawaiian plants by David Nelson in 1779. Hawaiian Plant Studies 55. Pacific Science 32:315-324.

St. John, H. 1979. Revision of the Genus Pandanus Stickman. Part 42 Pandanus tectorius Parkins. ex Z and Pandanus odoratissimus L.f. Pacific Science 33:395-401.

St. John, H. and F.R. Fosberg 1921-1934. Unpublished botanical survey data of the Mangareva Expedition. Bernice P. Bishop Museum, Honolulu, Hawaii.

St. John, H. and W.R. Philipson 1962. An account of the flora of Henderson Island, South Pacific Ocean. Transactions of the Royal Society of New Zealand 1:175-194.

Stokes, J.F.G. ms. Ethnology of Rapa. Unpublished manuscrupt in the Bernice P. Bishop Museum Archives, Honolulu, Hawaii.

Stone, B.C. 1976. The Pandanaceae of the New Hebrides, with an essay in intraspecific variation in Pandanus tectorius. Kew Bulletin 31:47-70.

Stone, B.C. 1988. Notes on the genus Pandanus (Pandanaceae) in Tahiti. Botanical Journal of the Linnean Society 97:33-48.

Sykes, W.R. 1977. Kermadec Island Flora: An annotated checklist. New Zealand Department of Scientific and Industrial Research Bulletin 219.

Sykes, W.R. and C.J. West 1996. New records and other information on the vascular flora of the Kermadec Islands. New Zealand Journal of Botany 34:447-462.

Teulat, B., C. Aldam, R. Trehin, P. Lebrun, J.H. Barker, G.M. Arnold, A. Karp, L. Baudouin and F. Rognon 2000. Analysis of genetic diversity in coconut (Cocos nucifera L.) populations from across the geographic range using sequence tagged microsatellites (SSRs) and AFLPs. Theoretical and Applied Genetics 100:764-771.

Vancouver, G. 1803. A voyage of discovery round the world. Cambridge: Hakluyt Society.

Wagner, W.L., D.R. Herbst and S.H. Sohmer 1990. Manual of the flowering plants of Hawaiti. Bernice P. Bishop Museum Special Publication 83.

Ward, R.G. and M. Brookfield 1992. The dispersal of the coconut: Did it float or was it carried to Panama? Journal of Biogeography 19:467-480.

Webb, C.J., W.R. Sykes and P.J. Garnock-Jones 1988. Flora of New Zealand Volume IV. Christchurch: Botany Division, D.S.I.R.

Weisler, M.I. 1995. Henderson Island prehistory: Colonization and extinction on a remote Polynesian island. Biological Journal of the Linnean Society 56:377-404.

Weisler, M.I. 1997. Prehistoric long-distance interaction at the margins of Oceania. In M.I. Weisler (ed), Prehistoric long-distance interaction in Oceania, pp. 149-172. New Zealand Archaeological Association Monograph.

Whistler, W.A. 1990. The other Polynesian gourd. Pacific Science 44:115-122.

Whistler, W.A. 1991. Polynesian plant introductions. In P.A. Cox and S.A. Banack (eds), Islands, plants, and Polynesians, pp. 41-66. Portland: Dioscorides Press.

Yen, D.E. 1973. The origins of oceanic agriculture, Archaeology and Physical Anthropology in Oceania 8:68-85.

Yen, D.E. 1974. The sweet potato and Oceania: An essay in ethnobotany. Honolulu: Bishop Museum Press.

Yen, D.E. and J. Head 1993. Kumara remains in pit O at P5/288. In D.G. Sutton (ed), The archaeology of the peripheral Pa at Pouerua, Northland, New Zealand, pp. 56-64. Auckland: Auckland University Press.

Zerega, N.J., D. Ragone and T.J. Motley 2004. Complex origins of breadfruit: Implications for human migrations in Oceania. American Journal of Botany 91:760-766.

Zizka, G. 1991. Flora of Easter Island. Palmarum Hortus Francofurtensis 3:1-108. 